Article

\title{
Effect of Vegetation Management and Site Conditions on Volume, Biomass and Leaf Area Allometry of Four Coniferous Species in the Pacific Northwest United States
}

\author{
Carlos A. Gonzalez-Benecke *(D), Herman N. Flamenco and Maxwell G. Wightman \\ Department of Forest Engineering, Resources and Management, Oregon State University, Corvallis, OR 97331, \\ USA; hnoeflamenco@gmail.com (H.N.F.); maxwell.wightman@oregonstate.edu (M.G.W.) \\ * Correspondence: carlos.gonzalez@oregonstate.edu; Tel.: +1-541-737-2103
}

Received: 23 August 2018; Accepted: 17 September 2018; Published: 19 September 2018

check for updates

\begin{abstract}
Allometric equations are useful tools for calculating tree and stand-level attributes, such as above-ground biomass or stem volume, using simple measurements that can be obtained from stand inventory data. These equations tend to be species-specific and can be affected by site conditions and silvicultural treatments. Forest vegetation management treatments (VM) are an important component of reforestation programs in the Pacific Northwest of the United States; however, no study has investigated the impact of these treatments on crop tree allometry. In this study we assessed the long-term effects of two contrasting VM treatments on the allometry of sixteen-year-old Douglas-fir, western hemlock, western redcedar, and grand fir trees growing in Oregon's central Coast Range (CR) and fifteen-year-old Douglas-fir and western redcedar trees growing in Oregon's Cascade foothills (CF). The VM treatments included a control which received only a pre-planting herbicide application and a VM treatment consisting of five consecutive years of vegetation control after planting. The equations developed in this study were species-specific and were not affected by VM with the exception of western redcedar foliage biomass. For western redcedar, tress of similar diameter had more foliage biomass when growing on plots without VM after planting. The allometry of Douglas-fir and western redcedar was also found to be affected by site, such that trees of similar diameter and height had larger stem volume when growing at the $\mathrm{CR}$ site than the $\mathrm{CF}$ site. This difference in stem volume was found to be the result of differences in stem tapering. There was a strong relationship between stand basal area and leaf area index that was the same for all species tested and was unaffected by site. The equations presented in this study are useful for calculating stem volume, leaf area and individual tree and component biomass for stands of the studied species that are of similar age.
\end{abstract}

Keywords: Douglas-fir; western hemlock; western redcedar; grand fir; above ground biomass functions; leaf area index; intensive silviculture; stand productivity; carbon sequestration

\section{Introduction}

Allometric equations are useful tools in forestry research that allow scientists to estimate a wide variety of variables from stand inventory data. One of the most common uses of allometric equations is estimating the above-ground biomass of both whole trees and different tree components such as foliage and branches [1]. Accurate estimates of forest above-ground biomass are of interest to researchers, forest managers and policy makers as this measure is necessary for determining site productivity and assessing stand and tree growth and yield [1,2]. Forest biomass estimates are also essential for determining forest carbon stocks and dynamics [3]. 
Allometric relationships exists among tree parts due to physical or physiological interrelations among stem dimensions, crown dimensions, foliage area, and biomass amounts [4]. Understanding these interactions, especially the relationship between tree dimeter and leaf area, is an important component of many mechanistic models of forest growth $[5,6]$. Allometric relationships tend to be species-specific and can be affected by site conditions or silvicultural treatments. For example, Brix (1984) [7] demonstrated that fertilizer application altered the relationship between foliage biomass and sapwood basal area for Douglas-fir trees growing in southern Vancouver Island, British Columbia. In contrast to this, Grier et al. (1984) [8] found that fertilizer application did not have a significant effect on the relationship between foliage biomass and sapwood area of Douglas-fir growing in central Washington State. The authors suggested that the reason for these conflicting results was due to differences in the soil fertility of study sites.

Competition between newly established seedlings and competing vegetation is a major process influencing seedling survival and growth $[9,10]$. In the Pacific Northwest (PNW) vegetation management treatments are commonly applied during reforestation projects and several studies have demonstrated an increase in seedling survival and growth rates due to vegetation management [11-15]. A majority of these studies, however, are relatively short-term (up to a couple of years) and no study has investigated the long-term (more than 15 years) effects of vegetation management on crop tree allometry.

Published allometric equations are available for the most commonly planted conifer species in the PNW region including Douglas-fir (Pseudotsuga menziesii (Mirbel) Franco), western hemlock (Tsuga heteophylla (Raf.) Sarg.), western redcedar (Thuja plicata Donn ex D. Don), and grand fir (Abies grandis (Dougl. ex D. Don) Lindl.), however none of these published equations account for vegetation management effects [16-19]. Assessing the potential impacts of vegetation management treatments on crop tree allometry is important to better account for long-term impacts of vegetation management on forest productivity and biomass stock. Additionally, many of the available allometric equations were developed over thirty years ago and there have been significant changes in nursery practices, silvicultural treatments, and seedling genetics since this time [20,21].

In this study we analyzed the long-term effects of contrasting vegetation management treatments on the allometry of fifteen to sixteen-year-old Douglas-fir, western hemlock, western redcedar and grand fir trees. Additionally, we analyzed the effects of site conditions on Douglas-fir and western redcedar allometry. The specific objectives were: (1) to develop allometric equations for Douglas-fir, western hemlock, western redcedar, and grand fir to predict stem volume, leaf area and component and total tree biomass from diameter at breast height (DBH, $1.37 \mathrm{~m}$ ) and height; (2) to assess the impact of sustained vegetation management during the first five years of stand establishment on crop tree allometry, and (3) to determine the effect of site conditions on the allometry of Douglas-fir and western redcedar.

\section{Materials and Methods}

\subsection{Study Sites}

Two sites in western central Oregon (OR) were selected for this study, one in the Coast Range (CR) and the other in the Cascade foothills (CF). The CR site $\left(44.62^{\circ} \mathrm{N}, 123.57^{\circ} \mathrm{W}\right)$ is located near Summit, OR, approximately $40 \mathrm{~km}$ from the coast and is characterized by a fine loamy soil, with $15 \%-20 \%$ soil organic matter concentration on top $50 \mathrm{~cm}$ soil, and pH of 4.9 and available soil water of $20 \%$ of top $100 \mathrm{~cm}$ soil layer, The $\mathrm{CR}$ site has a mean annual temperature of $11.1^{\circ} \mathrm{C}$ and a mean annual rainfall of $1707 \mathrm{~mm}$. The CF site $\left(44.48^{\circ} \mathrm{N}, 122.73^{\circ} \mathrm{W}\right)$ is located approximately $110 \mathrm{~km}$ from the coast near Sweet Home, OR, and is characterized by a silty clay loam soil, with $2 \%-4 \%$ soil organic matter concentration on top $50 \mathrm{~cm}$ soil, and pH of 5.4 and available soil water of $13 \%$ of top $100 \mathrm{~cm}$ soil layer. The CF site has a mean annual temperature of $12.4{ }^{\circ} \mathrm{C}$ and mean annual rainfall of $1179 \mathrm{~mm}$. A majority of the annual rainfall at both sites occurs between October to April. Figure 1 shows, for both sites, the patterns of 
cumulative rainfall Palmer Drought Severity Index (PDSI) for each growing season. Data was obtained from the Western Regional Climate Center (https:/ /wrcc.dri.edu/wwdt/time/). A negative PDSI indicates water deficit. Both sites had a negative PDSI during each of the first five growing seasons (age 1 to 5). The CF site had a lower PDSI (more water stress) than the CR site during the first three growing seasons (Figure 1b) even though the sites had similar rainfall during these growing seasons (May to September; M-S) (Figure 1a).
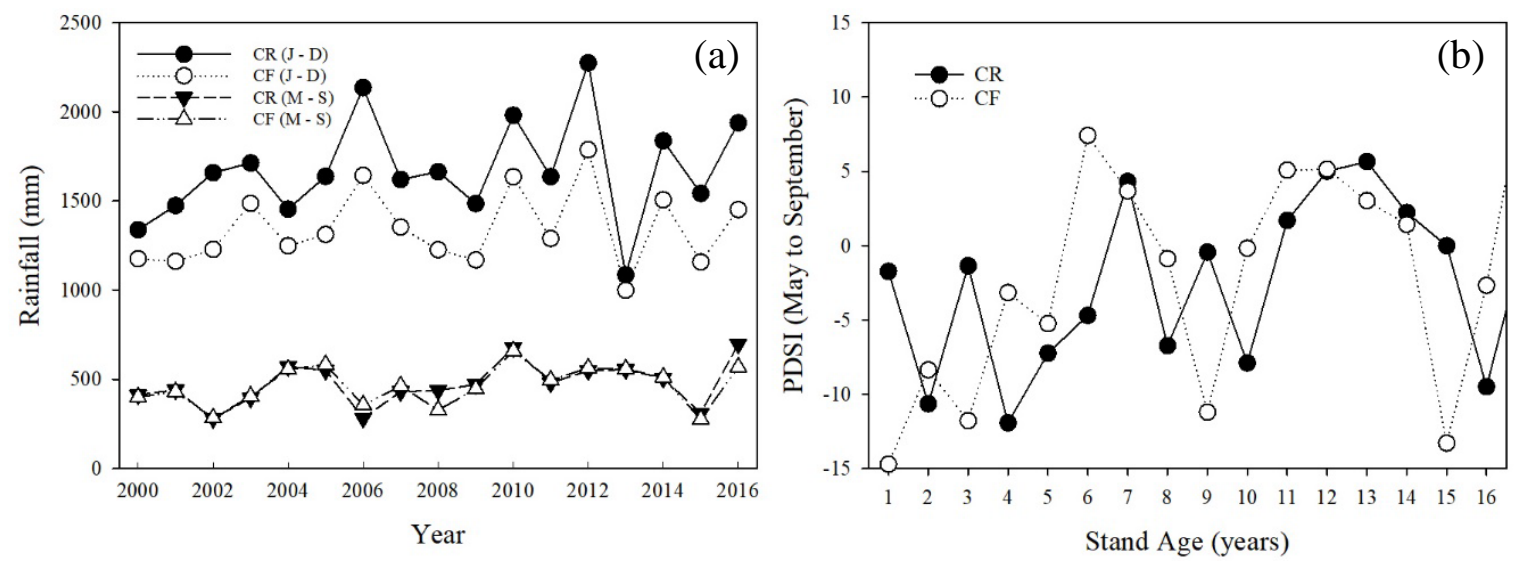

Figure 1. (a) Rainfall during the whole year (J-D; circles) and growing season (M-S; triangles) and (b) Palmer Drought Severity Index (PDSI) from growing season 1 to 16, for the study sites located in the central Coast Range (CR; filled symbol) and the Cascade foothills (CF; open symbol) of western Oregon.

Both study sites were established using a randomized complete-block design consisting of eight VM treatments. The CR site was planted in January of 2000 and the CF site was planted in February of 2001. A pre-planting fall herbicide application consisting of sulfometuron $\left(0.15 \mathrm{~L} \mathrm{ha}^{-1}\right)$, metsulfuron $\left(0.04 \mathrm{~L} \mathrm{ha}^{-1}\right)$, and glyphosate $\left(4.68 \mathrm{~L} \mathrm{ha}^{-1}\right)$ was applied to all plots at both sites. The eight VM treatments consisted of spring release applications that differed in the number and timing of herbicide treatments applied during the first 5 years of stand establishment. In the current study, only the control (C) and 5 consecutive years of spring release vegetation management treatments (VM) were used. The spring release treatments consisted of atrazine $\left(4.5-4.9 \mathrm{~kg} \mathrm{ha}^{-1}\right)$ and clopyralid $\left(0.58-0.73 \mathrm{~L} \mathrm{ha}^{-1}\right)$ and if the cover of competing vegetation in treated plots exceeded $25 \%$ during the growing season glyphosate $(1.5 \%-2.0 \%)$ was applied during the summer. The VM treatments significantly reduced the cover of competing vegetation and differences in vegetation cover persisted through the $16^{\text {th }}$ growing season (Figure 2). During these years, the percent cover of vegetation was determined in late summer on six- $1 \mathrm{~m}$ radius subplots per treatment plot. More information regarding the study design and treatments can be found in Maguire et al. (2009) [15].

Styro-15 seedlings were used at both sites for all crop tree species. Treatment plots consisted of eight tree by eight tree rows at a $3 \mathrm{~m}$ (10-ft) spacing (1076 trees per hectare) and stand inventories were conducted on the internal 6 rows of 6 trees allowing for a one tree buffer on all sides. Four coniferous species were planted at the CR site including: Douglas-fir (Pseudotsuga menziesii (Mirbel) Franco), western hemlock (Tsuga heterophylla (Raf.) Sarg.), western redcedar (Thuja plicata Donn ex D. Don), and grand fir (Abies grandis (Dougl. ex D. Don) Lindl.). The CR site contained four blocks of Douglas-fir and western hemlock, and three blocks for western redcedar and grand fir. Only Douglas-fir and western redcedar were planted at the CF site, each with four blocks. 


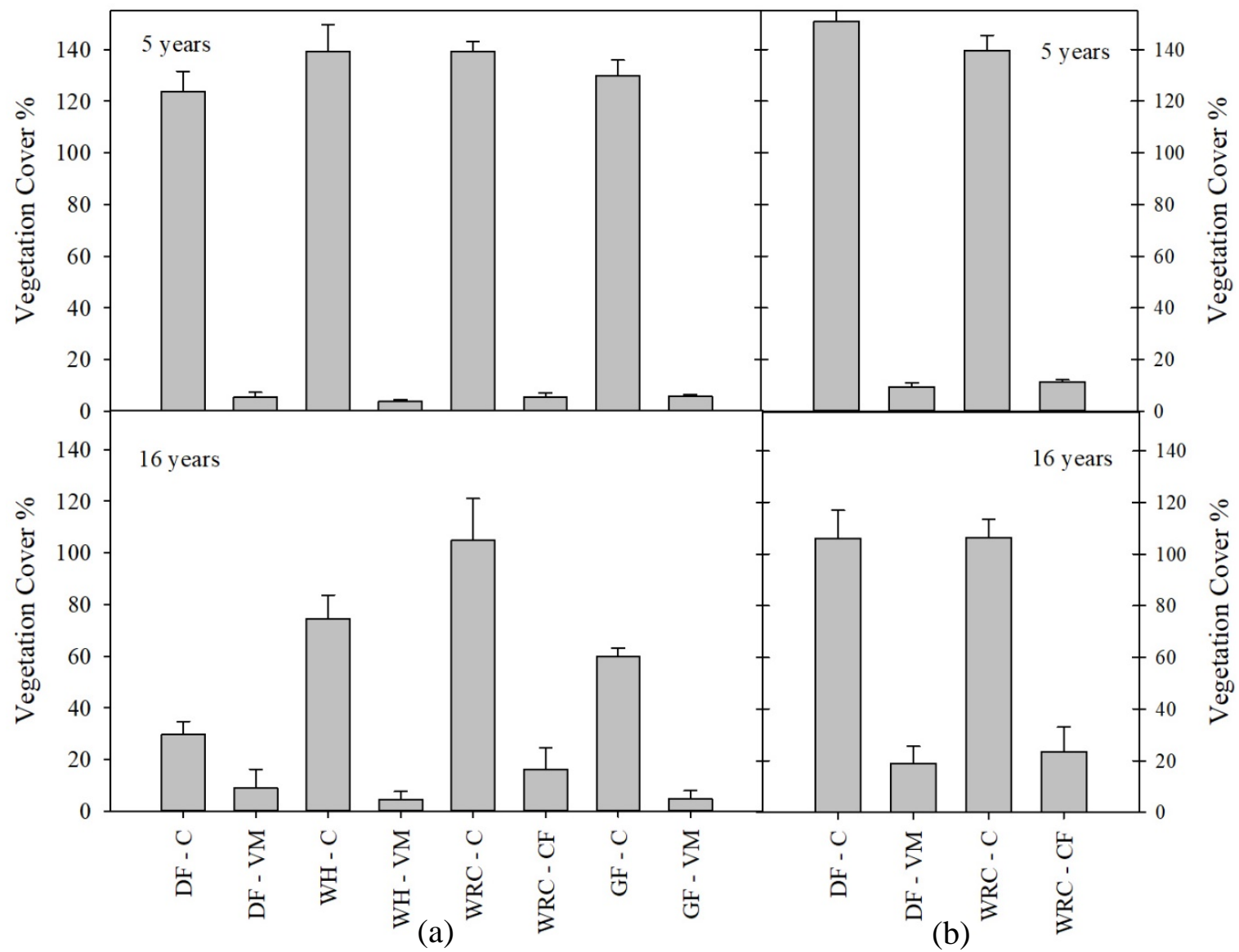

Figure 2. Summed percent cover (\%) of each species of competing vegetation on plots with no post-planting vegetation control (C) and plots with sustained vegetation control for the first 5 years post planting (vegetation management, (VM)) at ages 5 and 16 for Douglas-fir (DF), grand fir (GF), western hemlock $(\mathrm{WH})$ and western redcedar (WRC) stands growing on sites located in the central Coast Range (a) and the Cascade foothills (b) of western Oregon. Error bars represent standard error.

\subsection{Stand Inventory and Tree Biomass}

In March of 2016 (corresponding to age 16 years at the CR site and 15 years at the CF site), treatment plots at both study sites were inventoried. Metric diameter tapes $(\mathrm{mm})$ and a Haglof Vertex IV $(\mathrm{cm})$ was used to measure the DBH and height $(\mathrm{HT})$ of all living measurement trees. Table 1 summarizes stand characteristics at this time. On both sites, for all species, larger trees were found in the VM plots. For western redcedar, higher survival was also observed in the VM plots.

Sample trees for developing biomass allometric equations were selected using the inventory data. Trees were categorized by DBH into the following four classes: (1) between the 1st and 24th percentile, (2) the 25th and 49th percentile, (3) the 50th and 74th percentile, and (4) the 75th and 99th percentile. The mean DBH within each class was the target DBH for selected sample trees. These DBH targets were randomly assigned to a plot and the tree closest to the target DBH was selected from the buffer rows. Proximity to desired DBH and ease of felling were factors for tree selection. Four trees per species, treatment, and site were selected for biomass determination (32 trees at the CR site, 16 trees at the CF site). A summary of HT and DBH of sample trees is shown in Table 1. 
Table 1. Range of mean height (Height, $\mathrm{m}$ ), quadratic mean diameter (QMD, $\mathrm{cm}$ ), trees per ha (TPHA, $\left.\mathrm{ha}^{-1}\right)$, and basal area $\left(\mathrm{BA}, \mathrm{m}^{2} \mathrm{ha}^{-1}\right)$, as well as height $(\mathrm{HT}, \mathrm{m})$ and diameter at breast height $(\mathrm{DBH}$, $\mathrm{cm}$ ) of sample trees, for Douglas-fir (DF), western hemlock $(\mathrm{WH})$, western redcedar (WRC), and grand fir (GF) growing under contrasting treatments of vegetation management on sites located in the central Coast Range (CR; 16 years) and the Cascade foothills (CF; 15 years) of western Oregon. C: no post-planting vegetation control, VM: sustained vegetation control for first 5 years post planting.

\begin{tabular}{|c|c|c|c|c|c|c|c|c|}
\hline Site & Species & Treatment & Height (m) & QMD (cm) & TPHA $\left(\mathrm{ha}^{-1}\right)$ & BA $\left(m^{2} h a^{-1}\right)$ & $\mathrm{HT}^{*}(\mathrm{~m})$ & $\mathrm{DBH} *(\mathrm{~cm})$ \\
\hline \multirow{8}{*}{$\mathrm{CR}$} & \multirow[b]{2}{*}{$\mathrm{DF}$} & $\mathrm{C}$ & $13.4-14.5$ & $18.2-18.8$ & $598-718$ & $16.6-19.3$ & $14.3-17.2$ & $13.8-22.2$ \\
\hline & & $\mathrm{VM}$ & $14.0-15.7$ & $19.4-21.3$ & $688-718$ & $20.3-25.6$ & $14.8-17.4$ & $16.9-23.8$ \\
\hline & \multirow{2}{*}{ WH } & $C$ & $9.8-11.9$ & $11.8-16.4$ & 718-1047 & $9.1-17.3$ & $4.6-14.5$ & $3.8-18.3$ \\
\hline & & VM & $13.3-14.8$ & $18.2-21.5$ & $987-1047$ & $27.2-37.9$ & $14.9-16.5$ & $15.7-25.5$ \\
\hline & \multirow{2}{*}{ WRC } & $C$ & $3.8-5.7$ & $6.5-10.2$ & $748-838$ & $2.5-6.9$ & $4.5-10.6$ & $4.8-17.1$ \\
\hline & & $\mathrm{VM}$ & $8.0-8.6$ & $14.6-16.5$ & 838-1047 & $17.5-18.3$ & $3.6-9.6$ & $3.6-18.8$ \\
\hline & \multirow[b]{2}{*}{ GF } & $C$ & $7.8-9.5$ & $10.7-14.6$ & 868-987 & $8.4-14.6$ & $6.1-12.9$ & $6.6-19.1$ \\
\hline & & VM & $12.0-12.3$ & $18.6-21.4$ & $927-1047$ & $28.5-36.6$ & $8.6-14.0$ & $8.1-23.5$ \\
\hline \multirow{4}{*}{$\mathrm{CF}$} & \multirow{2}{*}{$\mathrm{DF}$} & $\mathrm{C}$ & $11.7-13.2$ & $15.1-15.6$ & 658-718 & $12.6-13.1$ & $9.7-15.2$ & $10.9-18.5$ \\
\hline & & $\mathrm{VM}$ & 13.9-14.5 & 18.9-20.0 & 718-718 & $20.2-22.5$ & $11.3-16.5$ & $15.5-23.1$ \\
\hline & \multirow{2}{*}{ WRC } & $C$ & $6.4-7.4$ & $12.2-13.2$ & 179-718 & $2.2-8.7$ & $6.3-8.7$ & 7.8-18.1 \\
\hline & & VM & $7.7-8.0$ & $13.7-14.4$ & 838-1017 & $13.2-15.6$ & $5.4-11.8$ & $8.2-21.3$ \\
\hline
\end{tabular}

*: Individual tree size of sample trees.

In June and July of 2016, all selected trees were felled. Once on the ground, the total length of the main stem $(\mathrm{cm})$ and the length of the living crown $(\mathrm{cm})$ of each tree were measured. The diameters of all branches were then measured at the stem insertion point using manual calipers $(\mathrm{mm},+/-1 \mathrm{~mm})$. The distance from the crown base $(\mathrm{cm})$ of each branch along the main stem was also recorded. Main stem diameter $(\mathrm{mm})$ and bark thickness $(\mathrm{mm})$ were measured at stump height $(50 \mathrm{~cm})$, breast height $(\mathrm{DBH}$, at $137 \mathrm{~cm})$ and every two meters from stump height using a metric diameter tape and a metric Haglof Barktax Bark Gauge, respectively.

Once the diameter at insertion point and position on the stem were recorded for all living and dead branches, the living crown of each tree was divided into thirds and two living branches were collected from each third ( 6 samples per tree, 24 samples per species per treatment per site). If there were dead branches below the start of the living crown, two dead branches were also collected on each tree. To facilitate manipulation of samples, a tarp was extended on the ground where sample branches were placed after being excised from the main stem. Later the sample branches were cut into smaller sections and placed into labeled bags. All samples were then placed in a cooler with ice packs to prevent needles from desiccating prior to area and mass determination. From the main stem, five cross sections of 5-10 cm in width were taken at: (1) stump height, (2) breast height, (3) between breast height and crown base, (4) crown base, and (5) between crown base and top of the tree. All cross sections were labeled with a red wax pencil and placed in a cooler with the branch samples. Samples that were not being processed during the same day were stored in a cold room at $8{ }^{\circ} \mathrm{C}$.

In the laboratory, each sample branch was separated into wood and foliage and placed in marked aluminum bins. From each sample branch, a subsample of foliage encompassing the full range of needle ages was placed in a bag, labeled, and stored in a refrigerator for later determination of specific leaf area. The wood and foliage of each sample branch was then placed in a Moore-Kiln REI TT drying oven which was set to $75^{\circ} \mathrm{C}$. Samples were left in the oven for at least $72 \mathrm{~h}$, until reaching constant weight. After that time, the weight $(\mathrm{g})$ of wood and foliage of each sample branch was determined using an OHAUS NV4101 scale (Parsippany, NJ, USA).

The diameter and thickness of each stem cross section was measured with a meter stick $(\mathrm{mm})$ in four directions by turning the sample $45^{\circ}$ clockwise. From the four diameter and thickness measurements taken from each of the five cross section samples, an average diameter and thickness was calculated for each cross section and the fresh volume for each sample (inside and outside bark) was determined as a cylinder $\left(\mathrm{cm}^{3}\right)$. Bark volume was then determined as the difference. The bark was 
then removed from the cross sections and both the bark and cross sections were placed in the drying oven for at least $72 \mathrm{~h}$ at $105^{\circ} \mathrm{C}$, until reaching constant weight. After that time, the dry weight of wood and bark of each disc sample was determined (g). Then the density of wood and bark was calculated as dry weight over fresh volume $\left(\mathrm{g} \mathrm{cm}^{-3}\right)$. These density determinations were later used to calculate dry weight of wood and bark of each sample tree.

\subsection{Specific Leaf Area and Leaf Area}

Projected specific leaf area (SLA, $\mathrm{m}^{2} \mathrm{~kg}^{-1}$ ) was estimated for each branch sample using the foliage subsample previously stored in the refrigerator. At least 60 needles were scanned for each Douglas-fir, western hemlock, and grand fir foliage subsample. For western redcedar at least one foliage spray was scanned from each subsample. The projected area of the needles and the foliage sprays was estimated on the scanned images using ImageJ software version IJ 1.46r (https:/ / imagej.nih.gov). Later, both the scanned foliage and the rest of the foliage subsample were placed in the drying oven for at least $72 \mathrm{~h}$ at $75{ }^{\circ} \mathrm{C}$. They were weighed separately and then added to the weight of the overall branch sample. The SLA of each branch was determined as the ratio between the projected area and the dry mass of each sample. Leaf area (LA, $\mathrm{cm}^{2}$ ) of each branch was calculated as the product of SLA and dry weight of foliage [22].

\subsection{Stem Volume and Dry Mass}

The volume of the wood and bark at each $2 \mathrm{~m}$ section was determined $\left(\mathrm{m}^{3}\right)$ using the stem diameter and bark thickness measurements. The volume for the stump ( $0.5 \mathrm{~m}$ in height) was calculated as a cylinder. The volume for the top of the tree was calculated as a cone. From the previously determined wood densities from the five cross-section samples per tree, a wood density was assigned to each $2 \mathrm{~m}$ interval depending on its position on the tree and the position at which the cross-section sample was derived. The dry weight $(\mathrm{kg})$ of wood and bark for each $2 \mathrm{~m}$ section was determined by multiplying the volume and the density. The sum of these values represents the dry weight of the stem wood and bark for the whole tree.

\subsection{Allometric Relationships}

Relationships between branch diameter $(\mathrm{Db}, \mathrm{mm})$ and insertion height within the main stem (Hr, the relative height from base of living crown) and foliage and woody (wood + bark) dry mass and foliage area of branches were developed by pooling all sample branches per species, treatment and site. Non-linear regression models were fitted to the branch samples to develop species-specific branch equations for dead branch wood + bark, live branch wood + bark, foliage mass, and leaf area. The structure of these models was:

$$
\mathrm{BF}, \mathrm{BW}, \mathrm{BD}, \mathrm{BLA}=a \cdot \mathrm{Db}^{b} \cdot \mathrm{Hr}^{c}
$$

where BF is branch foliage mass $(\mathrm{g})$, BW is branch wood + bark biomass $(\mathrm{g})$, BD is dead branch + bark biomass $(\mathrm{g})$, BLA is branch leaf area $\left(\mathrm{m}^{2}\right)$, $\mathrm{Db}$ is branch diameter, $\mathrm{Hr}$ is branch relative height from the base of the living crown and $a, b$, and $c$ are curve fit parameters.

For each species, in addition to diameter at branch insertion point ( $\mathrm{Db}, \mathrm{mm})$ and position on the main stem $(\mathrm{Hr})$, site and treatment were tested as covariates. Models were selected based on Bayesian Information Criterion (BIC) and the coefficient of determination $\left(R^{2}\right)$ values. The selected equations were then applied to the full set of branch measurements of all trees sampled within a species, treatment and site. The sum of these values resulted in the dry weight of the dead branchwood, live branchwood, foliage, and projected LA for the whole tree.

Once the field and lab measurements were completed and foliage and wood mass was determined for each sampled tree, species-specific models were developed to predict total tree leaf area, stem 
wood, bark, branch and foliage biomass, as well as stem volume over-bark and inside bark, from tree DBH and HT. The structure of these models was:

$$
\mathrm{W}, \mathrm{B}, \mathrm{F}, \mathrm{LB}, \mathrm{DB}, \mathrm{LA}, \mathrm{VOB}, \mathrm{VIB}=a \cdot \mathrm{DBH}^{b} \cdot \mathrm{HT}^{c}
$$

where $\mathrm{W}$ is stem wood biomass $(\mathrm{kg})$; B is stem bark biomass $(\mathrm{kg}) ; \mathrm{F}$ is foliage biomass $(\mathrm{kg})$; $\mathrm{LB}$ is living branch biomass $(\mathrm{kg})$; DB is dead branch biomass $(\mathrm{kg})$; LA is projected leaf area $\left(\mathrm{m}^{2}\right)$, VOB: stem volume over-bark $\left(\mathrm{m}^{3}\right)$; VIB: stem volume inside bark $\left(\mathrm{m}^{3}\right)$ and $a, b$, and $c$ are curve fit parameters. Models were selected based on BIC and $R^{2}$ values. After model development, the selected tree level species-specific equations were then applied to the age 16 years stand inventory. Each of these variables was then summed by plot and expressed on a hectare basis.

\subsection{Statistical Analysis and Model Fitting}

The Statistical Analysis Software version 9.4 (SAS Institute Inc., Cary, NC, USA) was used for all statistical analysis. Non-linear model fitting was used to estimate volume and biomass functions and analysis of variance, including Tukey multiple comparisons tests, was used to test the effects of treatments on tree allometry of all species. Treatment effects on the relationship with DBH or DBH and HT was carried out after log transformation of data (PROC NLIN and PROC MIXED; SAS Institute Inc., Cary, NC, USA). CurveExpert Professional version 2.6.3 (Hyams Development) was used for exploratory curve analysis. SigmaPlot version 13.0 (Systat Software, Inc. San Jose, CA, USA) was used to create all figures.

\subsection{Comparison Against Published Equations}

For all species, estimates of individual-tree total living aboveground biomass (TAGB $=\mathrm{W}+\mathrm{B}+$ $\mathrm{F}+\mathrm{LB})$ calculated using the equations reported in this study were compared against other models reported by Standish (1985) [18] and Chojnacky et al. (2014) [19]. Additionally, we compared the models reported by Shaw et al. (1979) [16] for western redcedar, and Gholz et al. (1982) [17] for Douglas-fir, western hemlock and grand fir. The generalized equations reported by Chojnacky et al. (2014) [19] used only DBH as the predictor, while the equations reported by Shaw (1979) [16], Gholz (1982) [17] and Standish (1985) [18] used DBH and HT as predictors. Two measures of accuracy were used to evaluate the goodness-of-fit between the observed and predicted values for TAGB: (1) mean bias error (Bias) and (2) root mean square error (RMSE).

\section{Results}

After eleven (CR site) or ten (CF site) years after treatments ended, there was no effect of VM treatment on the allometry of Douglas-fir, western hemlock or grand fir for any trait tested $(p>0.072$; Table 2). At the branch-level, only western redcedar showed a long-term effect of VM treatments on foliage biomass $(p<0.001))$ and leaf area $(p<0.001)$ allometry. For a given branch diameter size and location within the living crown, branches of western redcedar growing under the VM treatment had $25 \%$ less foliage mass and $26 \%$ less leaf area than branches of trees growing under the control treatment. Furthermore, there was a significant effect of site on western redcedar foliage mass branch-level allometry $(p=0.013)$. For a given branch diameter size and location within the living crown, branches of western redcedar trees growing at the $\mathrm{CF}$ site had $23 \%$ more foliage mass than at the CR site. 
Table 2. $p$-values of analysis of variance (ANOVA) testing effects of site, VM treatment (VM) and their interactions $(\mathrm{VM} \times$ Site) on branch $(\mathrm{BF}, \mathrm{BWB}, \mathrm{BD}$ and $\mathrm{BLA})$ and tree $(\mathrm{W}, \mathrm{B}, \mathrm{DB}, \mathrm{LB}, \mathrm{F}, \mathrm{LA}, \mathrm{VOB}$ and VIB) allometry for 15-16 year old Douglas-fir, western redcedar, western hemlock, and grand fir trees growing under contrasting treatments of vegetation management on sites located in the central Coast Range and the Cascade foothills of western Oregon. Bold: result is statistically significant at $p<0.05$.

\begin{tabular}{ccccccccc}
\hline \multirow{2}{*}{ Trait } & \multicolumn{3}{c}{ Douglas-Fir } & \multicolumn{3}{c}{ Western Redcedar } & Western Hemlock & Grand Fir \\
\cline { 2 - 8 } & $\mathbf{V M}$ & Site & VM $\times$ Site & VM & Site & VM $\times$ Site & VM & VM \\
\hline BF & 0.777 & 0.848 & 0.997 & $<\mathbf{0 . 0 0 1}$ & $\mathbf{0 . 0 1 3}$ & 0.234 & 0.072 & 0.301 \\
BWB & 0.961 & 0.944 & 0.302 & 0.277 & 0.509 & 0.933 & 0.433 & 0.196 \\
BD & 0.202 & 0.428 & 0.716 & - & - & - & 0.607 & 0.458 \\
BLA & 0.740 & 0.311 & 0.857 & $<\mathbf{0 . 0 0 1}$ & 0.213 & 0.892 & 0.083 & 0.725 \\
W & 0.156 & $\mathbf{0 . 0 0 8}$ & 0.343 & 0.612 & $\mathbf{0 . 0 0 7}$ & 0.272 & 0.680 & 0.991 \\
B & 0.711 & 0328 & 0.349 & 0.085 & 0.098 & 0.277 & 0.904 & 0.576 \\
DB & 0.480 & 0.712 & 0.961 & - & - & - & 0.661 & 0.180 \\
LB & 0.685 & 0.638 & 0.214 & 0.737 & 0.183 & 0.491 & 0.930 & 0.402 \\
F & 0.994 & 0.235 & 0.107 & $<\mathbf{0 . 0 0 1}$ & 0.153 & 0.062 & 0.972 & 0.232 \\
LA & 0.898 & 0.309 & 0.115 & 0.848 & 0.135 & 0.709 & 0.946 & 0.165 \\
VOB & 0.373 & $\mathbf{0 . 0 4 8}$ & 0.672 & 0.136 & $\mathbf{0 . 0 0 9}$ & 0.500 & 0.996 & 0.685 \\
VIB & 0.286 & $\mathbf{0 . 0 5 5}$ & 0.515 & 0.363 & $\mathbf{0 . 0 0 4}$ & 0.787 & 0.786 & 0.506 \\
\hline
\end{tabular}

BF is branch foliage biomass (g); BWB is live branch wood + bark biomass (g); BD is dead branch biomass (g); BLA is branch leaf area $\left(\mathrm{m}^{2}\right) ; \mathrm{W}$ is stemwood biomass $(\mathrm{kg})$; $\mathrm{B}$ is stembark biomass $(\mathrm{kg})$; $\mathrm{F}$ is foliage biomass $(\mathrm{kg})$; LB is living branch biomass $(\mathrm{kg})$; DB is dead branch biomass $(\mathrm{kg})$; LA is projected leaf area $\left(\mathrm{m}^{2}\right)$; VOB is stem volume over bark $\left(\mathrm{m}^{3}\right)$; VIB is stem volume inside bark $\left(\mathrm{m}^{3}\right)$.

At the tree-level, there was an effect of VM treatment on the allometry of foliage only for western redcedar trees $(p<0.001)$ and there was no long-term effect observed for any other species or trait tested ( $p>0.085$; Table 2). There was a significant effect of site on Douglas-fir and western redcedar stemwood biomass and stem volume allometry $(p<0.048)$. For a given DBH and HT, for both species, trees growing at the $\mathrm{CR}$ site had more stem volume and stemwood biomass than at the $\mathrm{CF}$ site.

\subsection{Branch Biomass}

Parameter estimates and fit statistics of the models to estimate wood + bark biomass, foliage biomass, and projected leaf area of branches of all species is shown in Table 3. Data were pooled in order to estimate functions that can be broadly applied. As there was a significant effect of site and VM treatment for western redcedar foliage biomass allometry, site and treatment specific functions are presented for this species. The $R^{2}$ of all models ranged between 0.84 and 0.98 . In most cases, including branch relative depth into the living crown (Hr) improved the model fitting. Dead branch biomass (BD) depended only on branch diameter at insertion point $(\mathrm{Db})$. These functions were used to estimate tree-level biomass and projected leaf area equations.

Even though there was no effect of site $(p=0.304)$ or VM treatment $(p=0.642)$ on the fraction of foliage to total branch biomass for Douglas-fir, western hemlock and grad fir, these species showed differences in the partitioning of branch components $(p<0.0001)$ and the number of branches per unit stem length $(p<0.0001)$. Figure 3 shows the mean values of fractional branch biomass and branch density across sites and treatments. The ratio of foliage to total branch biomass was largest for western redcedar, averaging $0.58(p<0.0001)$. There was no difference between Douglas-fir and western hemlock foliage to total branch biomass $(p=0.846)$ and both species averaged 0.4 (Figure 3a). Branch density, or the number of branches per $\mathrm{m}$ of stem, was lowest for western redcedar $(p<0.0001)$, averaging 12 branches per $m$ of stem length (Figure $3 b$ ). Grand fir had the largest branch density, averaging 29 branches per $m$ of stem length $(p<0.0001)$. 
Table 3. Parameter estimates and fit statistics of models to estimate branch foliage (BF), branch wood and bark (BWB), and dead branch (BD) biomass $(\mathrm{kg})$, as well as projected branch leaf area $\left(\mathrm{BLA}, \mathrm{m}^{2}\right)$, for 15-16 year old Douglas-fir (DF), western hemlock (WH), western redcedar (WRC), and grand fir (GF) trees growing under contrasting treatments of vegetation management on sites located in the central Coast Range and the Cascade foothills of western Oregon.

\begin{tabular}{|c|c|c|c|c|c|c|c|c|}
\hline Species & Component & Model & Parameter & Parameter Estimate & SE & $R^{2}$ & RMSE & $\mathrm{CV}$ \\
\hline \multirow{11}{*}{ DF } & \multirow{3}{*}{$\mathrm{BF}$} & \multirow{3}{*}{$=a \cdot \mathrm{D}_{\mathrm{b}}^{b} \cdot \mathrm{Hr}^{c}$} & $a$ & 0.242740 & 0.111243 & \multirow{3}{*}{0.900} & \multirow{3}{*}{43.874} & \multirow{3}{*}{41.9} \\
\hline & & & $b$ & 2.234609 & 0.153935 & & & \\
\hline & & & $c$ & 0.325534 & 0.070549 & & & \\
\hline & \multirow{3}{*}{ BWB } & \multirow{3}{*}{$=a \cdot \mathrm{D}_{\mathrm{b}}^{b} \cdot \mathrm{Hr}^{c}$} & $a$ & 0.104009 & 0.030414 & \multirow{3}{*}{0.969} & \multirow{3}{*}{40.342} & \multirow{3}{*}{24.3} \\
\hline & & & $b$ & 2.520137 & 0.093530 & & & \\
\hline & & & $c$ & -0.083128 & 0.023099 & & & \\
\hline & \multirow{2}{*}{$\mathrm{BD}$} & \multirow{2}{*}{$=a \cdot D_{b}^{b}$} & $a$ & 0.322141 & 0.157709 & \multirow{2}{*}{0.968} & \multirow{2}{*}{34.485} & \multirow{2}{*}{22.1} \\
\hline & & & $b$ & 2.175812 & 0.158788 & & & \\
\hline & & & $a$ & 0.001583 & 0.000812 & & & \\
\hline & BLA & $=a \cdot \mathrm{D}_{\mathrm{b}}^{b} \cdot \mathrm{Hr}^{c}$ & $b$ & 2.297381 & 0.170593 & 0.883 & 0.400 & 45.6 \\
\hline & & & $c$ & 0.266067 & 0.072168 & & & \\
\hline & & & $a$ & 0.409374 & 0.183901 & & & \\
\hline & $\mathrm{BF}$ & $=a \cdot \mathrm{D}_{\mathrm{b}}^{b} \cdot \mathrm{Hr}^{c}$ & $b$ & 2.079810 & 0.153200 & 0.899 & 26.031 & 40.9 \\
\hline & & & $c$ & 0.386665 & 0.080550 & & & \\
\hline & & & $a$ & 0.258027 & 0.100716 & & & \\
\hline & BWB & $=a \cdot \mathrm{D}_{\mathrm{b}}^{b} \cdot \mathrm{Hr}^{c}$ & $b$ & 2.172031 & 0.128320 & 0.953 & 28.206 & 28.8 \\
\hline WH & & & $c$ & -0.100870 & 0.030428 & & & \\
\hline & & & $a$ & 0.296655 & 0.161302 & & & \\
\hline & BD & $=a \cdot D_{\mathrm{b}}{ }^{b}$ & $b$ & 2.169103 & 0.172334 & 0.976 & 28.392 & 19.7 \\
\hline & & & $a$ & 0.006060 & 0.002824 & & & \\
\hline & BLA & $=a \cdot \mathrm{D}_{\mathrm{b}}^{b} \cdot \mathrm{Hr}^{c}$ & $b$ & 1.845332 & 0.160453 & 0.905 & 0.218 & 40.6 \\
\hline & & & $c$ & 0.302019 & 0.074047 & & & \\
\hline & & & $a$ & 0.887282 & 0.264078 & & & \\
\hline & $\mathrm{BF}$ & $a \cdot \mathrm{D}^{\bar{b}} \cdot \mathrm{Hr}^{c}$ & $b$ & 1.811325 & 0.094996 & 0.937 & 42.222 & 33.5 \\
\hline & & & $c$ & 0.101805 & 0.038719 & & & \\
\hline & & & $a$ & 0.414763 & 0.268685 & & & \\
\hline & $\mathrm{BF}_{\mathrm{CR}-\mathrm{C}}$ & $=a \cdot D_{b}^{b}$ & $b$ & 2.036934 & 0.212626 & 0.937 & 34.654 & 33.4 \\
\hline & & & $a$ & 0.226815 & 0.119741 & & & \\
\hline & $\mathrm{BF}_{\mathrm{CR}-\mathrm{VM}}$ & $=a \cdot \mathrm{D}_{\mathrm{b}}^{b} \cdot \mathrm{Hr}^{c}$ & $b$ & 2.255054 & 0.168183 & 0.973 & 24.922 & 25.1 \\
\hline & & & $c$ & 0.361523 & 0.100470 & & & \\
\hline & & & $a$ & 2.161440 & 0.987219 & 0.941 & 40.444 & 29.6 \\
\hline & $\mathrm{BF}_{\mathrm{C}-\mathrm{CF}}$ & $=a \cdot \mathrm{D}_{\mathrm{b}}{ }^{0}$ & $b$ & 1.497172 & 0.147314 & & & \\
\hline & & & $a$ & 0.225451 & 0.157968 & & & \\
\hline WRC & $\mathrm{BF}_{\mathrm{VM}-\mathrm{CF}}$ & $=a \cdot \mathrm{D}_{\mathrm{b}}^{b} \cdot \mathrm{Hr}^{c}$ & $b$ & 2.323746 & 0.225658 & 0.958 & 42.924 & 26.1 \\
\hline & & & $c$ & 0.264838 & 0.073860 & & & \\
\hline & & & $a$ & 0.043754 & 0.029673 & & & \\
\hline & BWB & $=a \cdot \mathrm{D}_{\mathrm{b}}^{b} \cdot \mathrm{Hr}^{c}$ & $b$ & 2.581373 & 0.206244 & 0.837 & 54.141 & 65.3 \\
\hline & & & $c$ & -0.135667 & 0.048691 & & & \\
\hline & & & $a$ & 0.025267 & 0.044227 & & 2127 & \\
\hline & $\mathrm{BD}$ & $=a \cdot \mathrm{D}_{\mathrm{b}}{ }^{0}$ & $b$ & 2.848520 & 0.752131 & 0.944 & 3.137 & 29.9 \\
\hline & & & $a$ & 0.003206 & 0.000994 & & & \\
\hline & BLA & $=a \cdot \mathrm{D}_{\mathrm{b}}{ }^{b}$ & $b$ & 1.853035 & 0.097849 & 0.935 & 0.198 & 33.8 \\
\hline & BI Ac & $-a D^{b}$ & $a$ & 0.006833 & 0.002779 & 0929 & 0208 & 358 \\
\hline & $\mathrm{BLA}_{\mathrm{C}}$ & $=a \cdot \mathrm{D}_{\mathrm{b}}{ }^{0}$ & $b$ & 1.623735 & 0.132254 & 0.929 & 0.208 & 35.8 \\
\hline & & & $a$ & 0.000931 & 0.000425 & & & \\
\hline & BLA $_{V M}$ & $=a \cdot D_{b}^{b}$ & $b$ & 2.229274 & 0.141052 & 0.959 & 0.164 & 27.7 \\
\hline & & & $a$ & 0.263667 & 0.184964 & & & \\
\hline & $\mathrm{BF}$ & $=\mathrm{D}_{\mathrm{b}}^{b} \cdot \mathrm{Hr}^{c}$ & $b$ & 2.201609 & 0.239199 & 0.841 & 37.831 & 55.7 \\
\hline & & & $c$ & 0.185972 & 0.074089 & & & \\
\hline & & & $a$ & 0.113294 & 0.048466 & & & \\
\hline & BWB & $=a \cdot \mathrm{D}_{\mathrm{b}}^{b} \cdot \mathrm{Hr}^{c}$ & $b$ & 2.338510 & 0.142954 & 0.956 & 21.431 & 30.0 \\
\hline GF & & & $c$ & -0.154903 & 0.024570 & & & \\
\hline & RD & $a^{b}$ & $a$ & 0.390743 & 0.296059 & 0942 & 37780 & 353 \\
\hline & BD & $=a \cdot \mathrm{D}_{\mathrm{b}}^{0}$ & $b$ & 2.091764 & 0.242813 & 0.943 & 37.788 & 35.3 \\
\hline & & & $a$ & 0.002418 & 0.001487 & & & \\
\hline & BLA & $=a \cdot \mathrm{D}_{\mathrm{b}}^{b} \cdot \mathrm{Hr}^{c}$ & $\mathrm{~b}$ & 2.141783 & 0.211811 & 0.875 & 0.226 & 46.0 \\
\hline & & & c & 0.311511 & 0.104361 & & & \\
\hline
\end{tabular}

$\mathrm{BF}$ is branch foliage biomass (kg); BWB is live branch biomass (kg); BD is dead branch biomass (kg); BLA is branch leaf area $\left(\mathrm{m}^{2}\right) ; \mathrm{D}_{\mathrm{b}}$ is branch diameter at insertion point $(\mathrm{mm}) ; \mathrm{Hr}$ is relative height; $\mathrm{SE}$ is the standard error; $R^{2}$ is coefficient of determination; RMSE is root mean square error (in the same unit as the corresponding variable); $\mathrm{CV}$ is coefficient of variation $(\%)$. 

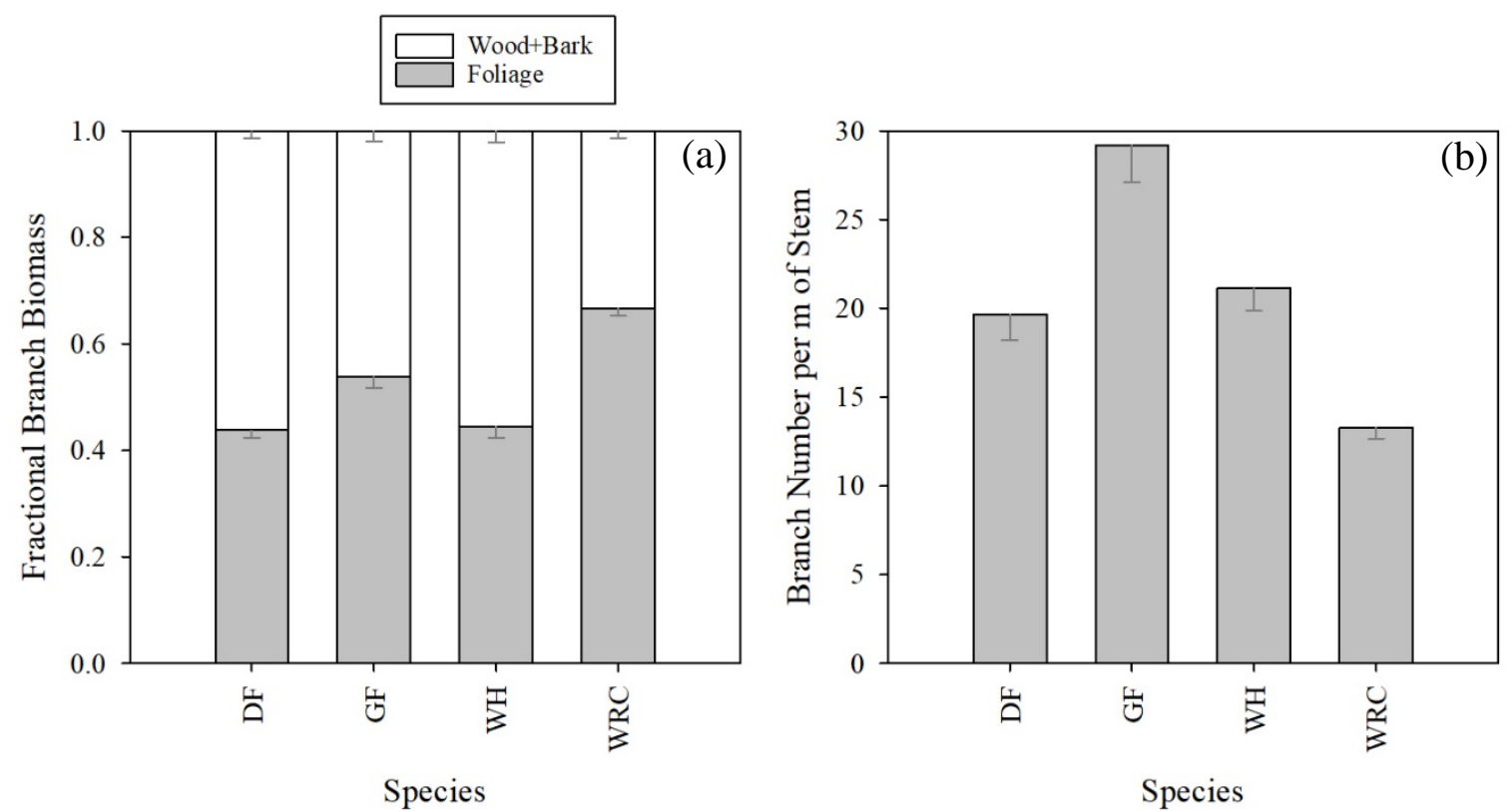

Figure 3. Branch biomass partitioning (a) and density (b) for 15-16-year-old Douglas-fir (DF), grand fir (GF), western hemlock (WH) and western redcedar (WRC) growing on sites located in the central Coast Range and the Cascade foothills of western Oregon. Error bars represents standard error.

\subsection{Stem Volume}

Parameter estimates and fit statistics of the models to estimate stem volume over bark (VOB, $\mathrm{m}^{3}$ ) and volume inside bark (VIB, $\left.\mathrm{m}^{3}\right)$ for planted Douglas-fir, western hemlock, western redcedar, and grand fir are shown in Table 4. Even though there was an effect of site for Douglas-fir and western redcedar, data was pooled in order to estimate volume functions that can be broadly applied. For both species, site-specific functions are also presented. The $R^{2}$ was larger than 0.99 for all species and sites. For western redcedar, height was not a significant parameter for estimating VOB or VIB. The relationship between DBH and VOB for each species in shown in Figure 4a. Grand fir and western redcedar followed a similar pattern, having, for a given DBH, lower VOB than Douglas-fir and western hemlock.

Differences in stem tapering across sites were observed for the basal section for Douglas-fir and western redcedar trees (Figure 5). The ratio between stem diameter at $0.5 \mathrm{~m}$ height and DBH (Figure $5 \mathrm{a}$ ) was bigger for Douglas-fir $(p=0.0008)$ and western redcedar $(p=0.037)$ growing at the CR site. At $2 \mathrm{~m}$ height and above (Figure $5 b, c$ ) there was no difference in the ratio of the stem diameter at that height and DBH across sites $(p>0.17)$. The sum of branch area at insertion point on three stem sections is shown in the lower panel of Figure 5. All branches between ground line and $1 \mathrm{~m}$ height were associated with stem diameter at $0.5 \mathrm{~m}$ (Figure $5 \mathrm{~d}$ ), all branches between 1.5 and $2.5 \mathrm{~m}$ height were associated with stem diameter at $2 \mathrm{~m}$ (Figure $5 \mathrm{e}$ ) and all branches between 3.5 and $4.5 \mathrm{~m}$ height were associated with stem diameter at $4 \mathrm{~m}$ (Figure $5 \mathrm{f}$ ). Larger cumulative branch area on the basal section $(0-1 \mathrm{~m}$ height) was observed for Douglas-fir ( $57 \%$ increase) and western redcedar ( $37 \%$ increase) trees growing at the CR site (Figure 5d). At upper stem sections (Figure 5e,f) there was no difference between sites in the cumulative branch area. There was no difference between sites in the number of branches for any section of the stem (data not shown). 
Table 4. Stem Volume functions and fit statistics for 15-16-year-old Douglas-fir (DF), western hemlock $(\mathrm{WH})$, western redcedar (WRC), and grand fir (GF) trees growing under contrasting treatments of vegetation management on sites located in the central Coast Range and the Cascade foothills of western Oregon.

\begin{tabular}{|c|c|c|c|c|c|c|c|}
\hline Species & Model & Parameter & $\begin{array}{l}\text { Parameter } \\
\text { Estimate }\end{array}$ & $\mathrm{SE}$ & $R^{2}$ & RMSE & CV \\
\hline \multirow{18}{*}{ DF } & \multirow{3}{*}{$\mathrm{VOB}=a \cdot \mathrm{DBH}^{b} \cdot \mathrm{HT}^{c}$} & $a$ & 0.000055 & 0.000027 & \multirow{3}{*}{0.996} & \multirow{3}{*}{0.014} & \multirow{3}{*}{6.9} \\
\hline & & $b$ & 1.703752 & 0.203596 & & & \\
\hline & & $c$ & 1.190193 & 0.306222 & & & \\
\hline & \multirow{3}{*}{$* \mathrm{VOBCR}=a \cdot \mathrm{DBH}^{b} \cdot \mathrm{HT}^{c}$} & $a$ & 0.000102 & 0.000117 & \multirow{3}{*}{0.996} & \multirow{3}{*}{0.016} & \multirow{3}{*}{6.7} \\
\hline & & $b$ & 1.8385 & 0.2893 & & & \\
\hline & & $c$ & 0.8307 & 0.6082 & & & \\
\hline & \multirow{3}{*}{$* \mathrm{VOBCF}=a \cdot \mathrm{DBH}^{b} \cdot \mathrm{HT}^{c}$} & $a$ & 0.000146 & 0.000041 & \multirow{3}{*}{0.999} & \multirow{3}{*}{0.005} & \multirow{3}{*}{3.2} \\
\hline & & $b$ & 2.3508 & 0.2107 & & & \\
\hline & & $c$ & 0.1037 & 0.287 & & & \\
\hline & \multirow{3}{*}{$\mathrm{VIB}=a \cdot \mathrm{DB} H^{b} \cdot \mathrm{HT}^{c}$} & $a$ & 0.000034 & 0.000018 & \multirow{3}{*}{0.995} & \multirow{3}{*}{0.012} & \multirow{3}{*}{7.5} \\
\hline & & $b$ & 1.671631 & 0.219626 & & & \\
\hline & & $c$ & 1.327253 & 0.333032 & & & \\
\hline & \multirow{3}{*}{$* \mathrm{VIBCR}=a \cdot \mathrm{DBH}^{b} \cdot \mathrm{HT}^{c}$} & $a$ & 0.000054 & 0.000066 & \multirow{3}{*}{0.995} & \multirow{3}{*}{0.014} & \multirow{3}{*}{7.1} \\
\hline & & $b$ & 1.7884 & 0.3071 & & & \\
\hline & & $c$ & 1.0374 & 0.6467 & & & \\
\hline & \multirow{3}{*}{$* \mathrm{VIBCF}=a \cdot \mathrm{DBH}^{b} \cdot \mathrm{HT}^{c}$} & $a$ & 0.000104 & 0.000042 & \multirow{3}{*}{0.998} & \multirow{3}{*}{0.006} & \\
\hline & & $b$ & 2.401 & 0.3005 & & & 4.6 \\
\hline & & $c$ & 0.0946 & 0.4104 & & & \\
\hline & & $a$ & 0.000027 & 0.000019 & & & \\
\hline & $\mathrm{VOB}=a \cdot \mathrm{DBH}^{b} \cdot \mathrm{HT}^{c}$ & $b$ & 2.027001 & 0.099639 & 0.997 & 0.009 & 6.3 \\
\hline WH & & $c$ & 1.083405 & 0.242174 & & & \\
\hline & & $a$ & 0.000018 & 0.000016 & & & \\
\hline & $\mathrm{VIB}=a \cdot \mathrm{DBH}^{b} \cdot \mathrm{HT}^{c}$ & $b$ & 1.890755 & 0.129699 & 0.995 & 0.011 & 8.2 \\
\hline & & $c$ & 1.335256 & 0.308443 & & & \\
\hline & & $a$ & 0.000177 & 0.000052 & & & \\
\hline & $\mathrm{VOB}=a \cdot \mathrm{DBH}^{b}$ & $b$ & 2.2539 & 0.1023 & 0.993 & 0.006 & 10.3 \\
\hline & & $a$ & 0.000256 & 0.000078 & & & \\
\hline & $* \mathrm{VOBCR}=a \cdot \mathrm{DBH}^{b}$ & $b$ & 2.1418 & 0.1085 & 0.997 & 0.004 & 7.2 \\
\hline & & $a$ & 0.000111 & 0.000039 & & & \\
\hline WRC & $* \mathrm{VOBCF}=a \cdot \mathrm{DBH}^{b}$ & $b$ & 2.4007 & 0.119 & 0.996 & 0.006 & 8.2 \\
\hline & $\mathrm{VIB}=a \cdot \mathrm{DBH}^{b}$ & $a$ & 0.000148 & 0.000051 & 0991 & 0006 & 122 \\
\hline & $\mathrm{VIB}=a \cdot \mathrm{DBH}^{\circ}$ & $b$ & 2.2559 & 0.1213 & 0.991 & 0.006 & 12.2 \\
\hline & & $a$ & 0.00024 & 0.000073 & 0.997 & 0.004 & 74 \\
\hline & $* \mathrm{VIBCR}=a \cdot \mathrm{DBH}^{\circ}$ & $b$ & 2.1086 & 0.1086 & 0.997 & 0.004 & 7.4 \\
\hline & & $a$ & 0.00008 & 0.000031 & 0.995 & 0.005 & 9.1 \\
\hline & $* \mathrm{VIBCF}=a \cdot \mathrm{DBH}^{v}$ & $b$ & 2.4494130 & 0.1327910 & 0.995 & 0.000 & 9.1 \\
\hline & & $a$ & 0.0000392 & 0.0000100 & & & \\
\hline & $\mathrm{VOB}=a \cdot \mathrm{DBH}^{b} \cdot \mathrm{HT}^{c}$ & $b$ & 2.0478170 & 0.0756310 & 0.999 & 0.004 & 4.0 \\
\hline GF & & $c$ & 0.9230922 & 0.1050010 & & & \\
\hline & & $a$ & 0.0000170 & 0.0000070 & & & \\
\hline & $\mathrm{VIB}=a \cdot \mathrm{DBH}^{b} \cdot \mathrm{HT}^{c}$ & $b$ & 2.2572040 & 0.1190240 & 0.998 & 0.006 & 6.0 \\
\hline & & $c$ & 0.9347452 & 0.1599140 & & & \\
\hline
\end{tabular}

VOB is stem volume outside bark $\left(\mathrm{m}^{3}\right)$; VIB is stem volume inside bark $\left(\mathrm{m}^{3}\right)$; DBH is stem diameter at $1.37 \mathrm{~m}$ height $(\mathrm{cm})$; HT is total height $(\mathrm{m})$; SE is the standard error; $R^{2}$ is coefficient of determination; RMSE is root mean square error; CV is coefficient of variation (\%). *: Site-specific function for WRC. Sub index: CR: Coast Range; CF: Cascade foothills. 

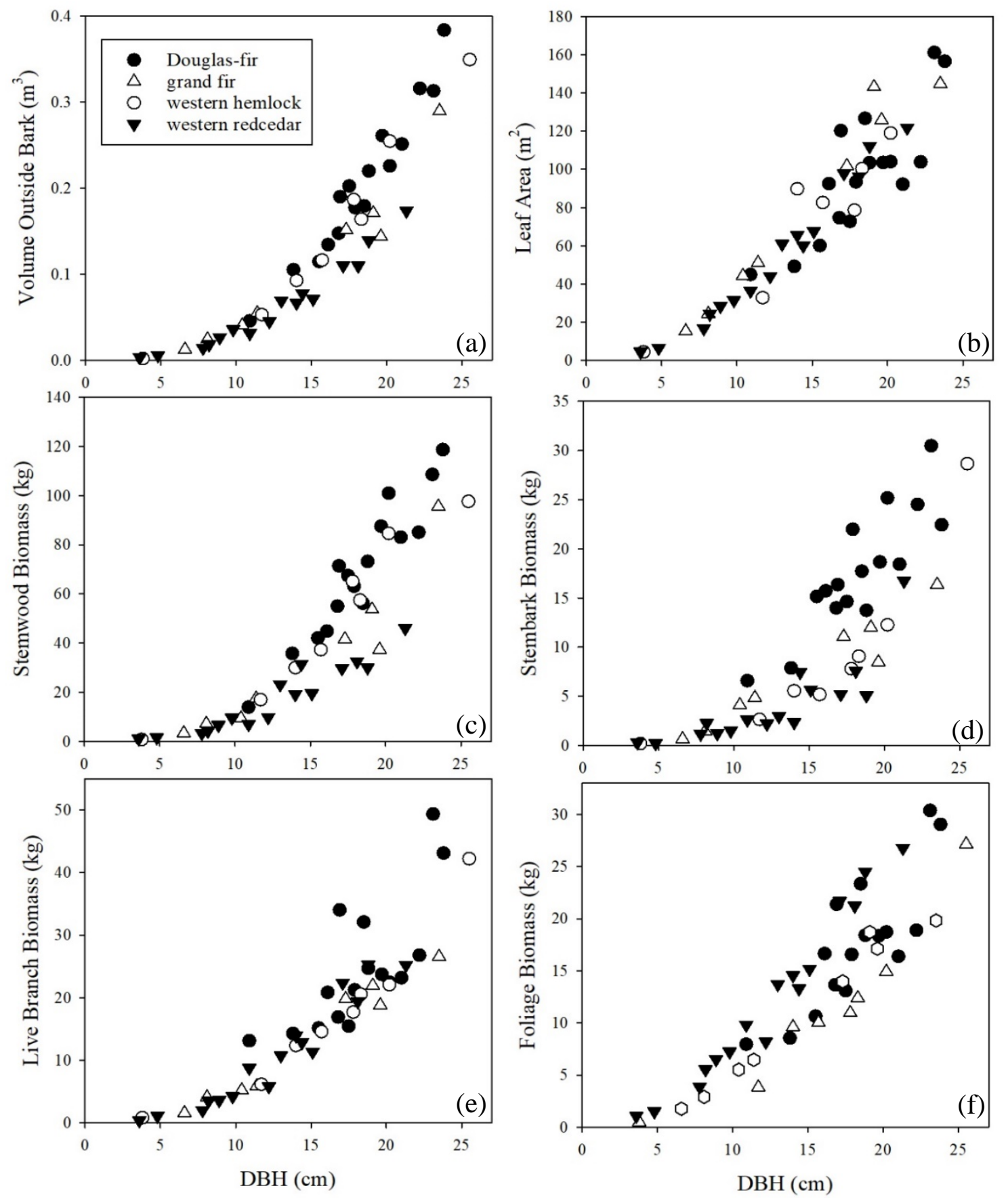

Figure 4. Relationship between diameter at breast height (DBH) and (a) stem volume over-bark, (b) leaf area, (c) stemwood biomass, (d) stembark biomass, (e) live branch biomass and (f) foliage biomass, for 15-16-year-old Douglas-fir (filled circle), grand fir (open triangle), western hemlock (open circle) and western redcedar (filled triangle) growing on sites located in the central Coast Range and the Cascade foothills of western Oregon. 


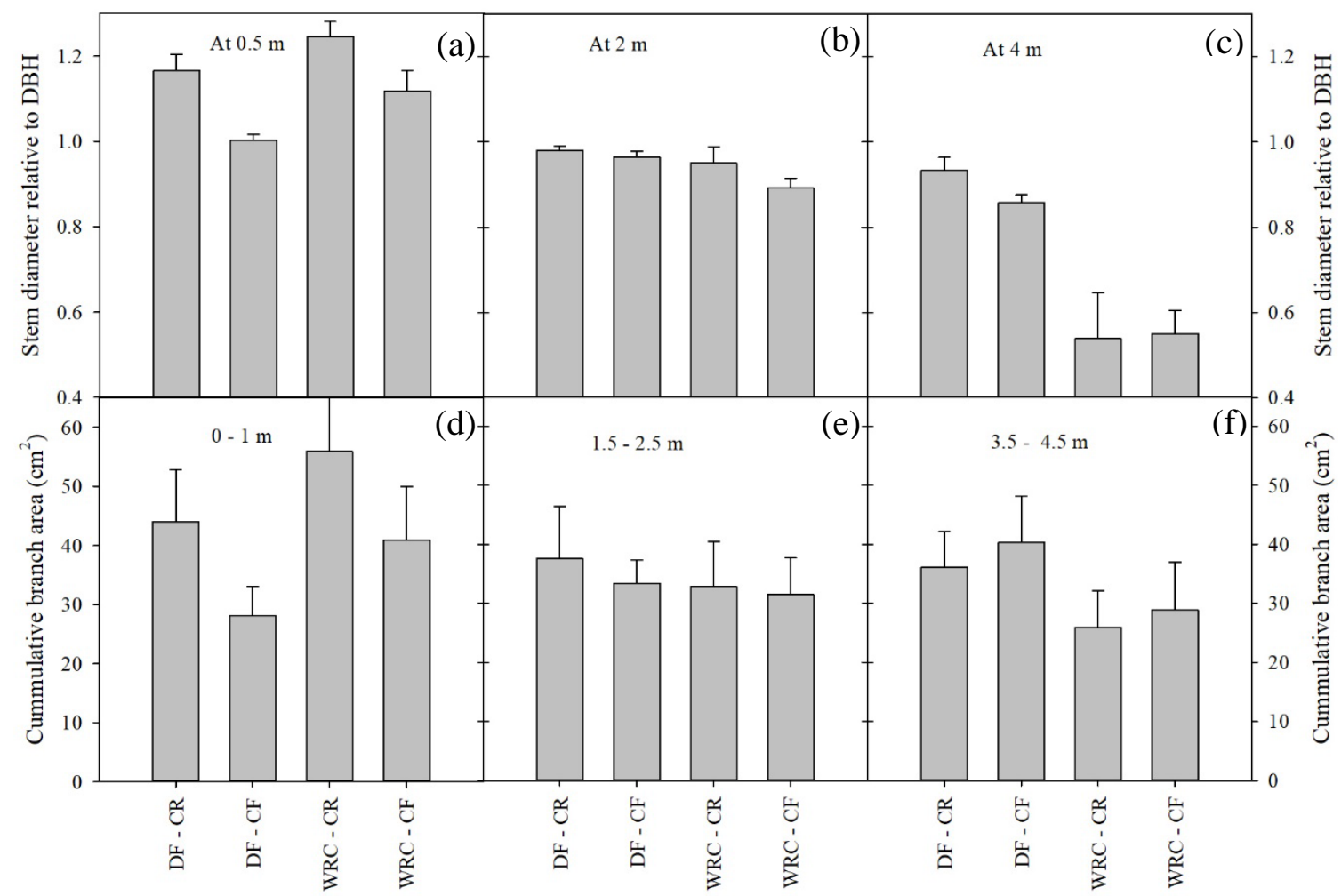

Figure 5. Ratio of stem diameter at $0.5 \mathrm{~m} \mathrm{(a),} 2 \mathrm{~m} \mathrm{(b)}$ and $4 \mathrm{~m} \mathrm{(c)} \mathrm{height} \mathrm{to} \mathrm{stem} \mathrm{diameter} \mathrm{at} \mathrm{breast}$ height $(\mathrm{DBH})$ and cumulative branch cross section area at insertion point $\left(\mathrm{cm}^{2}\right)$ between ground line and $1 \mathrm{~m} \mathrm{(d),} 1.5$ to $2.5 \mathrm{~m}$ (e) and between 3.5 to $4.5 \mathrm{~m}$ (f) stem height for 15-16-year-old Douglas-fir (DF) and western redcedar (WRC) growing on sites located in the central Coast Range (CR) and the Cascade foothills (CF) of western Oregon.

Parameter estimates and fit statistics of the models to estimate stem wood (W), stem bark (B), live branch (LB), dead branch (DB), and foliage (F) biomass $\left(\mathrm{kg}^{-1} \mathrm{tree}^{-1}\right)$, as well as projected leaf area $\left(\mathrm{LA}, \mathrm{m}^{2}\right.$ tree $\left.{ }^{-1}\right)$, are shown in Table 5. Similar to stem volume, there were no differences in parameter estimates across sites $(p>0.32)$ and data was pooled. Overall, $R^{2}$ ranged between 0.74 and 0.99. For Douglas-fir and western hemlock trees, $\mathrm{W}$ depended on DBH and HT. For grand fir, W biomass depended only on DBH and western redcedar depended only on HT. For all species, all other variables, including LA, depended only on DBH. The exception was B for grand fir which depended on both, DBH and HT. The relationships between DBH and LA, W, B, LB and F for each species is shown in Figure $4 \mathrm{~b}-\mathrm{f}$. Western redcedar showed, for a given $\mathrm{DBH}$, lower $\mathrm{W}$ and higher $\mathrm{F}$ than the other species, reflecting a different pattern in biomass allocation. Overall, all species showed a similar relationship between DBH and LA. Douglas-fir showed, for a given DBH, larger B than the other species. We observed a positive relationship $(p<0.001)$ between tree size (DBH or HT) and the number of living branches per tree (data not shown), a result in agreement with the foliar biomass functions reported in Table 5 . 
Table 5. Parameter estimates and fit statistics of the models to estimate stem wood (W), stem bark (B), live branch (LB), dead branch (DB), and foliage (F) biomass $\left(\mathrm{kg}\right.$ tree $\left.{ }^{-1}\right)$, as well as projected leaf area $\left(\mathrm{LA}, \mathrm{m}^{2}\right.$ tree $^{-1}$ ), for 15-16-year-old Douglas-fir (DF), western hemlock (WH), western redcedar (WRC), and grand fir (GF) trees growing under contrasting treatments of vegetation management on sites located in the central Coast Range and the Cascade foothills of western Oregon.

\begin{tabular}{|c|c|c|c|c|c|c|c|c|}
\hline Species & Component & Model & Parameter & Parameter Estimate & SE & $R^{2}$ & RMSE & $\mathrm{CV}$ \\
\hline \multirow{13}{*}{ DF } & \multirow{3}{*}{ W } & \multirow{3}{*}{$=a \cdot \mathrm{DBH}^{b} \cdot \mathrm{HT}^{c}$} & $a$ & 0.085982 & 0.079190 & \multirow{3}{*}{0.983} & \multirow{3}{*}{9.548} & \multirow{3}{*}{13.8} \\
\hline & & & $b$ & 1.743391 & 0.410895 & & & \\
\hline & & & $c$ & 0.588628 & 0.592671 & & & \\
\hline & \multirow{2}{*}{ B } & \multirow{2}{*}{$=a \cdot \mathrm{DBH}^{b}$} & $a$ & 0.143963 & 0.124467 & \multirow{2}{*}{0.970} & \multirow{2}{*}{3.237} & \multirow{2}{*}{18.3} \\
\hline & & & $b$ & 1.650530 & 0.289199 & & & \\
\hline & \multirow{2}{*}{ F } & \multirow{2}{*}{$=a \cdot \mathrm{DBH}^{b}$} & $a$ & 0.127946 & 0.126649 & \multirow{2}{*}{0.962} & \multirow{2}{*}{3.663} & \multirow{2}{*}{20.8} \\
\hline & & & $b$ & 1.687964 & 0.330921 & & & \\
\hline & \multirow{2}{*}{ LB } & \multirow{2}{*}{$=a \cdot \mathrm{DBH}^{b}$} & $a$ & 0.091734 & 0.124809 & \multirow{2}{*}{0.934} & 6883 & 278 \\
\hline & & & $b$ & 1.914700 & 0.453363 & & 6.883 & 27.8 \\
\hline & & & $a$ & 0.013202 & 0.040815 & & & \\
\hline & DB & $=a \cdot \mathrm{DBH}^{b}$ & $b$ & 2.257778 & 1.025492 & 0.744 & 6.009 & 61.2 \\
\hline & & & $a$ & 0.809925 & 0.790337 & & & \\
\hline & LA & $=a \cdot \mathrm{DBH}^{b}$ & $b$ & 1.671241 & 0.326305 & 0.962 & 21.795 & 20.6 \\
\hline & & & $a$ & 0.007047 & 0.004370 & & & \\
\hline & W & $=a \cdot \mathrm{DBH}^{b} \cdot \mathrm{HT}^{c}$ & $b$ & 1.571966 & 0.097645 & 0.99 & 2.928 & 6.00 \\
\hline & & & $c$ & 1.662778 & 0.219399 & & & \\
\hline & $\mathrm{P}$ & & $a$ & 0.000498 & 0.000253 & & & \\
\hline & B & $=a \cdot \mathrm{DBH}^{0}$ & $b$ & 3.381269 & 0.161567 & 0.995 & 0.888 & 9.95 \\
\hline & & & $a$ & 0.022128 & 0.011911 & 0900 & 1225 & 119 \\
\hline WH & $\mathrm{F}$ & $=a \cdot \mathrm{DBH}^{v}$ & $b$ & 2.189509 & 0.175570 & 0.990 & 1.335 & 11.9 \\
\hline & I R & & $a$ & 0.026507 & 0.010002 & 0.995 & 1410 & 832 \\
\hline & LB & $=a \cdot \mathrm{DBH}^{v}$ & $b$ & 2.271618 & 0.122826 & 0.995 & 1.419 & 8.32 \\
\hline & & & $a$ & 0.048264 & 0.087975 & & & \\
\hline & DB & $=a \cdot \mathrm{DBH}^{b}$ & $b$ & 1.531550 & 0.605645 & 0.888 & 1.482 & 37.2 \\
\hline & $\mathrm{I} A$ & & $a$ & 0.378075 & 0.186953 & & & \\
\hline & LA & $=a \cdot \mathrm{DBH}^{b}$ & $b$ & 1.942013 & 0.162359 & 0.991 & 10.329 & 11.2 \\
\hline & & & $a$ & 0.084895 & 0.057711 & & & \\
\hline & W & $=a \cdot \mathrm{DBH}^{b}$ & $b$ & 2.053715 & 0.237990 & 0.961 & 4.275 & 24.9 \\
\hline & P & & $a$ & 0.000772 & 0.001259 & & & \\
\hline & B & $=a \cdot \mathrm{DBH}^{0}$ & $b$ & 3.204432 & 0.556574 & 0.892 & 1.870 & 46.1 \\
\hline & F & & $a$ & 0.140835 & 0.039597 & 0992 & 1320 & 109 \\
\hline WRC & & $=a \cdot \mathrm{DBH}^{0}$ & $b$ & 1.736489 & 0.099446 & 0.992 & 1.329 & 10.9 \\
\hline & I B & $\mathrm{DPH}^{b}$ & $a$ & 0.048643 & 0.028102 & ר 070 & 2245 & 211 \\
\hline & LB & $=a \cdot \mathrm{DBH}^{\sigma}$ & $b$ & 2.083644 & 0.202075 & 0.972 & 2.245 & 21.1 \\
\hline & קח & & $a$ & 0.003620 & 0.009308 & & & \\
\hline & DB & $=a \cdot \mathrm{DBH}^{b}$ & $b$ & 1.825111 & 1.152156 & 0.938 & 0.044 & 29.2 \\
\hline & $\mathrm{I} A$ & & $a$ & 0.632243 & 0.197693 & & & \\
\hline & LA & $=a \cdot \mathrm{DBH}^{b}$ & $b$ & 1.764259 & 0.110488 & 0.989 & 7.109 & 12.1 \\
\hline & & & $a$ & 0.001790 & 0.001526 & & & \\
\hline & W & $=a \cdot \mathrm{DBH}^{b} \cdot \mathrm{HT}^{c}$ & $b$ & 2.367067 & 0.238453 & 0.969 & 4.664 & 31.8 \\
\hline & & & $c$ & 1.292649 & 0.331163 & & & \\
\hline & $R_{2}$ & & $a$ & 0.054515 & 0.050308 & 0967 & 1628 & 2 \\
\hline & B & $=a \cdot \mathrm{DBH}^{0}$ & $b$ & 1.799409 & 0.308392 & 0.967 & 1.638 & 22.2 \\
\hline & & & $a$ & 0.141392 & 0.084277 & 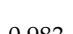 & 1 & 155 \\
\hline GF & $\mathrm{F}$ & $=a \cdot \mathrm{DBH}^{v}$ & $b$ & 1.599511 & 0.200387 & 0.983 & 1.675 & 15.5 \\
\hline & I P & & $a$ & 0.096273 & 0.069479 & 0979 & 2265 & 174 \\
\hline & LB & $=a \cdot \mathrm{DBH}^{v}$ & $b$ & 1.799857 & 0.241167 & 0.979 & 2.265 & 17.4 \\
\hline & $\mathrm{DR}$ & $\mathrm{DPH}^{b}$ & $a$ & 0.000009 & 0.000035 & 0809 & 2407 & 420 \\
\hline & DB & $=a \cdot \mathrm{DBH}^{v}$ & $b$ & 4.570093 & 1.150185 & 0.899 & 2.497 & 42.9 \\
\hline & LA & & $a$ & 1.015881 & 0.615344 & 0.982 & 11524 & 159 \\
\hline & LA & $=a \cdot \mathrm{DBH}^{\circ}$ & $b$ & 1.575135 & 0.203806 & 0.902 & 11.024 & 10.9 \\
\hline
\end{tabular}

$\mathrm{W}$ is stem wood biomass $(\mathrm{kg})$; $\mathrm{B}$ is stem bark biomass $(\mathrm{kg})$; $\mathrm{F}$ is foliage biomass $(\mathrm{kg})$; LB is living branch biomass $(\mathrm{kg})$; DB is dead branch biomass $(\mathrm{kg})$; LA is projected leaf area $\left(\mathrm{m}^{2}\right)$; DBH is stem diameter at $1.37 \mathrm{~m} \mathrm{height}(\mathrm{cm})$; $\mathrm{HT}$ is total height $(\mathrm{m})$; SE is the standard error; $R^{2}$ is coefficient of determination; RMSE is root mean square error (in the same unit as the corresponding variable); CV is coefficient of variation (\%). 
The species evaluated showed differences in the partitioning of aboveground biomass to the different components of the tree. The effect of site on the partitioning of aboveground biomass was significant only for bark of western redcedar $(p<0.001)$. For all other species and biomass components, there were no differences across sites $(p>0.155)$. Figure 6 shows the mean values across sites. The ratio of stemwood to total aboveground biomass was not different $(p>0.301)$ between Douglas-fir $(0.488)$, western hemlock (0.521) and grand fir (0.435). Western redcedar trees had a smaller stemwood to total aboveground biomass ratio (0.373) and that value was not different to grand fir $(p=0.166)$. Douglas-fir had the largest proportion of stembark to total aboveground biomass (0.131), followed by grand fir (0.107), western hemlock (0.091) and western redcedar (0.089). Western redcedar showed a negligible amount of dead branches and the ratio of crown (foliage + branches) to total aboveground biomass was larger for western redcedar (0.537) and smaller for Douglas-fir (0.381) and western hemlock (0.388).
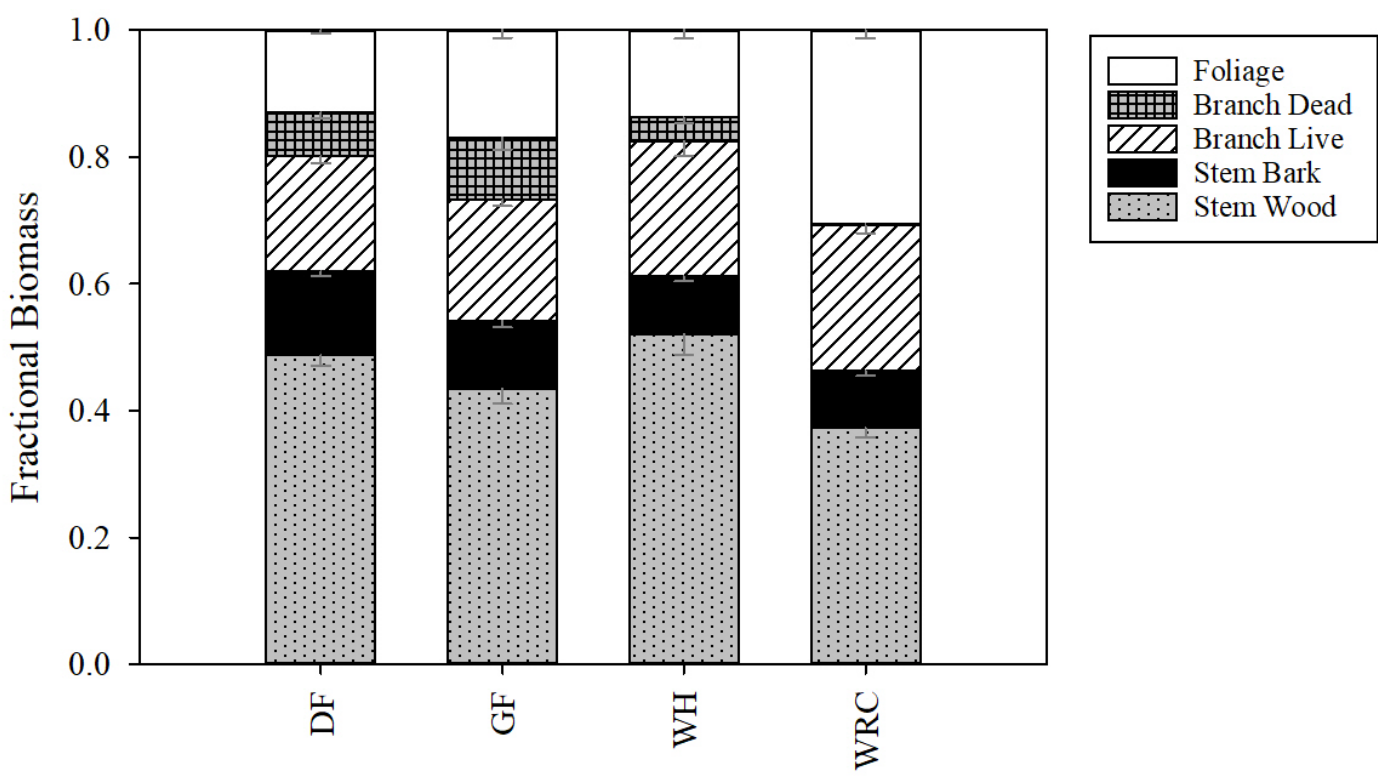

Species

Figure 6. Biomass partitioning for 15-16-year-old Douglas-fir (DF), grand fir (GF), western hemlock (WH) and western redcedar (WRC) growing on sites located in the central Coast Range and the Cascade foothills of western Oregon.

There was a strong relationship between foliage dry mass and area, and between stem volume and mass for each species. The slope of each relationship corresponds to the overall SLA $\left(\mathrm{m}^{2} \mathrm{~kg}^{-1}\right.$; Figure $7 \mathrm{a}$ ) and wood density (DW, $\mathrm{kg} \mathrm{m}^{-3}$; Figure $\mathrm{7b}$ ). There were no differences in the slope of the relationship between foliage dry mass and projected leaf area between western hemlock and grand fir $(p=0.232)$, and in the slope of the relationship between stem volume and mass between western hemlock, western redcedar and grand fir $(p>0.121)$.

Average SLA, stem wood density (DW), and bark density (DB) or each species and site are shown in Table 6. As there was no effect of VM treatments on SLA $(p>0.07)$, DW $(p>0.09)$ and BD $(p>0.09)$, data was pooled across VM treatments. At the CR site, western hemlock had the largest SLA $\left(8.30 \mathrm{~m}^{2}\right.$ $\left.\mathrm{kg}^{-1}\right)$, followed by grand fir $\left(7.82 \mathrm{~m}^{2} \mathrm{~kg}^{-1}\right)$, Douglas-fir $\left(5.59 \mathrm{~m}^{2} \mathrm{~kg}^{-1}\right)$ and western redcedar $\left(4.41 \mathrm{~m}^{2}\right.$ $\left.\mathrm{kg}^{-1}\right)$. Only western hemlock and grand fir showed non-significant differences $(p=0.188)$. At the CF site, Douglas-fir had significantly higher SLA than western redcedar $(p<0.001)$, averaging 5.53 and $4.48 \mathrm{~m}^{2} \mathrm{~kg}^{-1}$, respectively. 

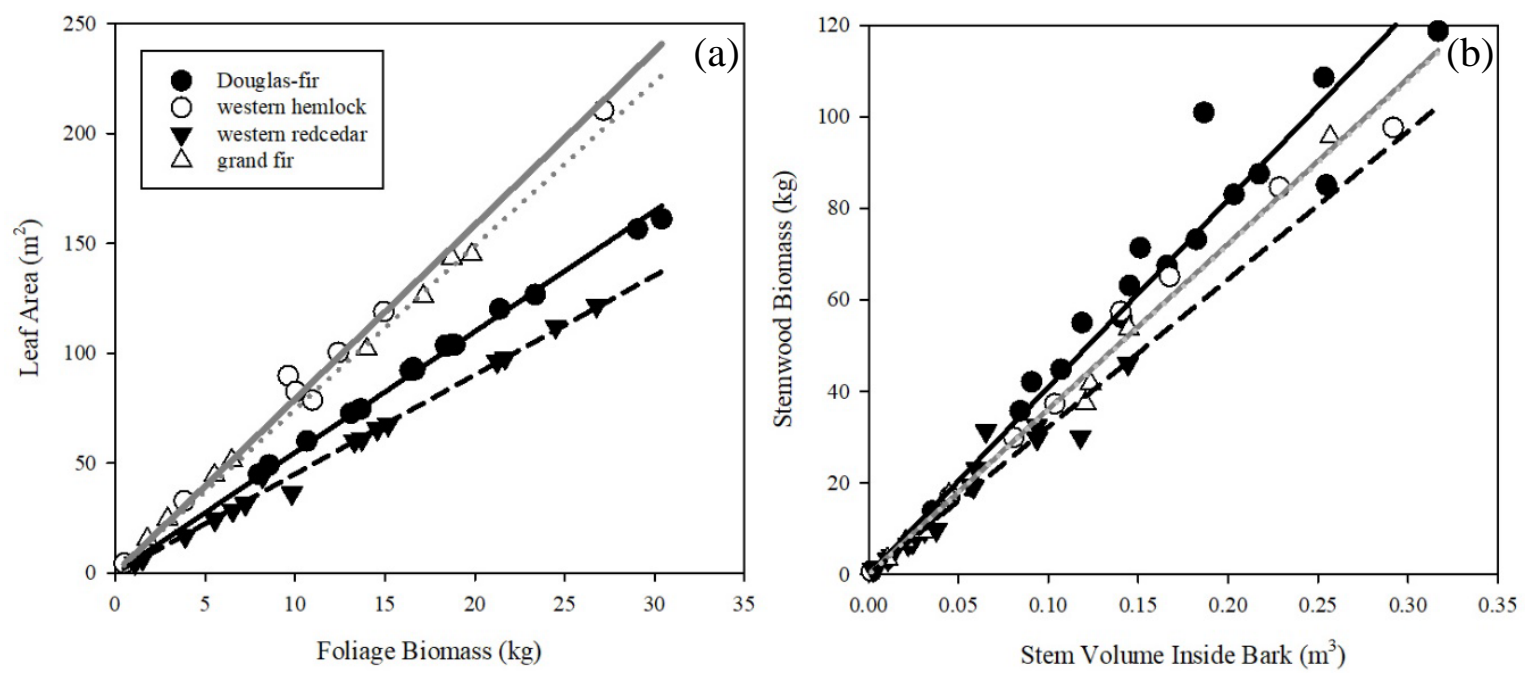

Figure 7. Relationships between (a) foliage biomass and leaf area, and (b) stem volume inside bark and stemwood biomass for 15-16-year-old Douglas-fir (filled circle), grand fir (open triangle), western hemlock (open circle) and western redcedar (filled triangle) growing on sites located in the central Coast Range and the Cascade foothills of western Oregon.

Table 6. Average specific leaf area (SLA, $\mathrm{m}^{2} \mathrm{~kg}^{-1}$ ), stemwood density (DW, $\mathrm{kg} \mathrm{m}^{-3}$ ) and bark density $\left(\mathrm{DB}, \mathrm{kg} \mathrm{m}^{-3}\right.$ ) for destructively sampled 15-16-year-old Douglas-fir (DF), western hemlock (WH), western redcedar (WRC) and grand fir (GF) trees growing on sites located in the central Coast Range (CR) and the Cascade foothills (CF) of western Oregon.

\begin{tabular}{|c|c|c|c|c|c|}
\hline \multirow{2}{*}{ Species } & \multirow{2}{*}{ Variable } & \multicolumn{2}{|c|}{ CR } & \multicolumn{2}{|c|}{$C F$} \\
\hline & & Mean & SE & Mean & SE \\
\hline \multirow{3}{*}{$\mathrm{DF}$} & SLA & 5.59 & 0.04 & 5.53 & 0.05 \\
\hline & DW & 398.7 & 11.92 & 394.4 & 10.43 \\
\hline & DB & 382.2 & 13.51 & 392.2 & 11.20 \\
\hline \multirow{3}{*}{ WH } & SLA & 8.30 & 0.28 & & \\
\hline & DW & 396.5 & 15.68 & & \\
\hline & DB & 420.6 & 25.74 & & \\
\hline \multirow{3}{*}{ WRC } & SLA & 4.41 & 0.05 & 4.48 & 0.17 \\
\hline & DW & 328.7 & 10.34 & 335.4 & 8.96 \\
\hline & $\mathrm{DB}$ & 309.0 & 15.16 & 329.8 & 10.58 \\
\hline \multirow{3}{*}{ GF } & SLA & 7.82 & 0.20 & & \\
\hline & DW & 343.3 & 11.98 & & \\
\hline & DB & 416.2 & 17.71 & & \\
\hline
\end{tabular}

SLA: Specific leaf area $\left(\mathrm{m}^{2} \mathrm{~kg}^{-1}\right)$; DW: stemwood density $\left(\mathrm{kg} \mathrm{m}^{-3}\right)$; DB: stembark density $\left(\mathrm{kg} \mathrm{m}^{-3}\right)$; SE: standard error.

There was no difference in DW of Douglas-fir and western redcedar trees across sites (Table 6). At the CR site, Douglas-fir had the largest DW $\left(399 \mathrm{~kg} \mathrm{~m}^{-3}\right)$, followed by western hemlock $\left(397 \mathrm{~kg} \mathrm{~m}^{-3}\right)$, grand fir $\left(343 \mathrm{~kg} \mathrm{~m}^{-3}\right)$ and western redcedar $\left(329 \mathrm{~kg} \mathrm{~m}^{-3}\right)$. Only western redcedar showed significant differences with Douglas-fir $(p=0.022)$ and western hemlock $(p=0.028)$. At the CF site, Douglas-fir and western redcedar had average DW of about 394 and $335 \mathrm{~kg} \mathrm{~m}^{-3}$, respectively $(p<0.001)$. There was no effect of site $(p=0.12)$ or VM treatment $(p=0.096)$ on DB. At the CR site, western hemlock had the largest DB $\left(421 \mathrm{~kg} \mathrm{~m}^{-3}\right)$, followed by grand fir $\left(416 \mathrm{~kg} \mathrm{~m}^{-3}\right)$, Douglas-fir $\left(382 \mathrm{~kg} \mathrm{~m}^{-3}\right)$ and western redcedar $\left(309 \mathrm{~kg} \mathrm{~m}^{-3}\right)$. Western redcedar had significant lower DB than the other species $(p<0.029)$. At the CF site, Douglas-fir and western redcedar had average DB of about 392 and $330 \mathrm{~kg} \mathrm{~m}^{-3}$, respectively $(p=0.004)$. 


\subsection{Comparison against Published Equations}

For all species, the equations presented in this study to estimate TAGB produced the highest accuracy and precision (Table 7). The predictive ability of the reported equations varied for the different species. For Douglas-fir, the equations reported by Standish (1985) [18] presented the highest RMSE and Bias. For western hemlock, estimates using the equation reported by Gholz (1982) [17] showed the largest Bias and RMSE and the equations reported by Gholz (1982) [17] and Chojnacky et al. (2014) [19] presented intermediate performance. For western redcedar, all reported equations tested showed poor prediction ability, especially those reported by Shaw (1979) [16] and Standish (1985) [18] that showed RMSE larger than 50\%. For grand fir, even though the Bias of the functions reported by Gholz (1982) [17] and Chojnacky et al. (2014) [19] was low (less than 1.7\% underestimations), the RMSE was more than 2 times larger than the equations reported in this study (Table 7).

Table 7. Comparison of mean absolute bias (Bias) and root mean square error (RMSE) between the models reported in this study and three functions reported in scientific literature for total living aboveground biomass (TAGB; $\mathrm{kg}_{\text {tree }}{ }^{-1}$ ) for Douglas-fir (DF), western hemlock (WH), western redcedar (WRC), and grand fir (GF) trees.

\begin{tabular}{|c|c|c|c|c|c|}
\hline Species & Source & $\bar{O}$ & $\bar{P}$ & Bias & RMSE \\
\hline \multirow{4}{*}{ DF } & This study & \multirow{4}{*}{129.3} & 129.4 & -0.07 & 11.5 \\
\hline & Chojnacky et al. (2014) [19] & & 123.8 & 4.26 & 14.0 \\
\hline & Gholz (1982) [17] & & 134.1 & -3.64 & 15.5 \\
\hline & Standish (1985) [18] & & 111.5 & 13.8 & 20.3 \\
\hline \multirow{4}{*}{$\mathrm{WH}$} & This study & \multirow{4}{*}{85.9} & 85.7 & 0.29 & 4.2 \\
\hline & Chojnacky et al. (2014) [19] & & 86.4 & -0.54 & 11.0 \\
\hline & Gholz (1982) [17] & & 101.3 & -17.87 & 26.0 \\
\hline & Standish (1985) [18] & & 94.5 & -9.98 & 18.7 \\
\hline \multirow{4}{*}{ WRC } & This study & \multirow{4}{*}{44.1} & 44.3 & -0.2 & 12.5 \\
\hline & Chojnacky et al. (2014) [19] & & 34.7 & 9.36 & 26.7 \\
\hline & Shaw (1979) [17] & & 25.5 & 18.53 & 50.8 \\
\hline & Standish (1985) [18] & & 56.1 & -11.99 & 51.4 \\
\hline \multirow{4}{*}{ GF } & This study & \multirow{4}{*}{64.4} & 64.0 & 0.44 & 6.1 \\
\hline & Chojnacky et al. (2014) [19] & & 66.0 & -1.64 & 15.3 \\
\hline & Gholz (1982) [17] & & 64.7 & -0.29 & 17.6 \\
\hline & Standish (1985) [18] & & 73.5 & -9.07 & 26.1 \\
\hline
\end{tabular}

$\bar{O}$ : observed mean TAGB (kg); $\bar{P}$ : predicted mean TAGB (kg); Bias: mean absolute bias (observed-predicted; \%); RMSE: root mean square error $(\%)$.

\subsection{Leaf Area Index and Basal Area}

Stand basal area $\left(\mathrm{BA}, \mathrm{m}^{2} \mathrm{ha}^{-1}\right)$ and projected leaf area index (LAI, $\left.\mathrm{m}^{2} \mathrm{~m}^{-2}\right)$ were calculated using the leaf area equations shown in Table 4 and the inventory data collected in year 2016 at both sites. There was a strong linear relationship between BA and LAI. All species across both sites shared the same relationship ( $\left.p<0.001, R^{2}=0.98\right)$ (Figure 8 ). On average, a stand with a BA of $20 \mathrm{~m}^{2} \mathrm{ha}^{-1}$ has a LAI of about $7.5 \mathrm{~m}^{2} \mathrm{~m}^{-2}$. Parameter estimates and fit statistics for the relationships between BA and projected LAI are shown in Table A1. On average, for every $1 \mathrm{~m}^{2} \mathrm{ha}^{-1}$ BA increment, LAI increased by $0.367 \mathrm{~m}^{2} \mathrm{~m}^{-2}$. 


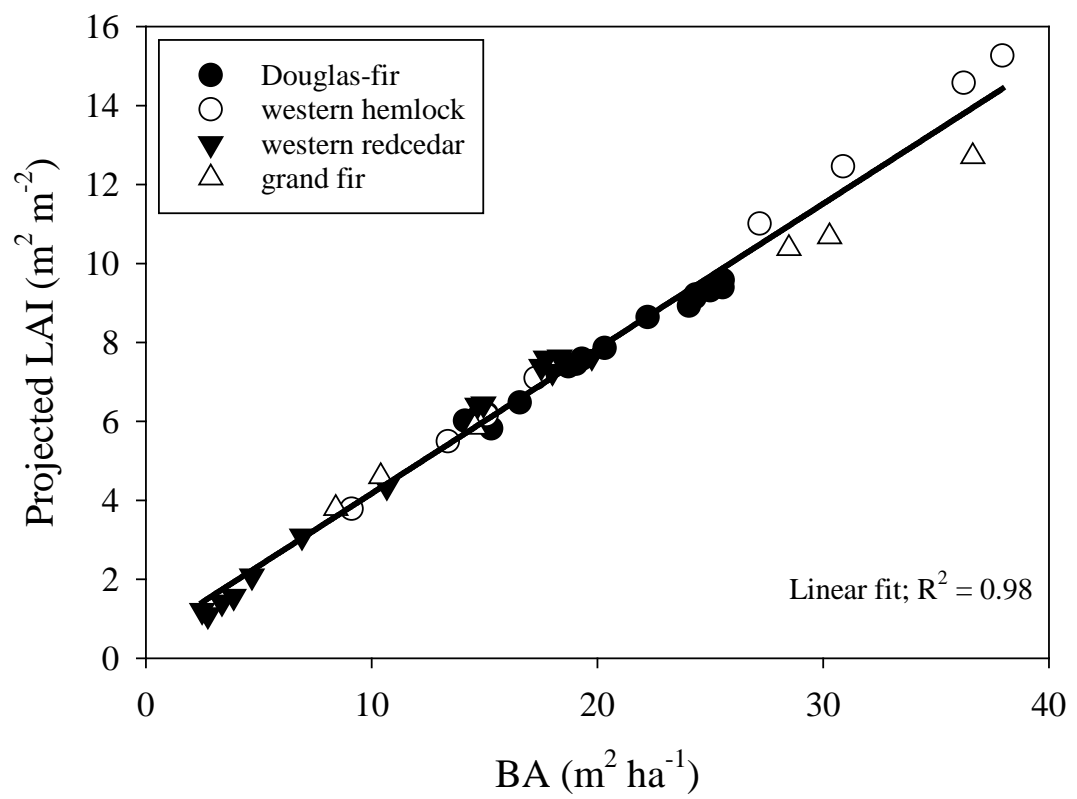

Figure 8. Relationship between basal area (BA, $\left.\mathrm{m}^{2} \mathrm{ha}^{-1}\right)$ and projected leaf area index $\left(\mathrm{LAI}, \mathrm{m}^{2} \mathrm{~m}^{-2}\right.$ ) for 15-16-year-old Douglas-fir, western hemlock, western redcedar, and grand fir stands. A single relationship was shared for all species growing under contrasting treatments of vegetation control on both sites.

\section{Discussion}

The research presented in this study represents one of the few attempts to quantify long-term responses in branch-level and tree-level allometry in response to VM treatments carried out during the establishment period of conifer plantations. The responses observed were site-and species-specific, indicating differences across species in their ability to compete for site resources, and differences across sites in the level of competition and the amount of resources available. Species-specific biomass and stem volume functions were developed for all four conifer species tested in this study. These functions are useful for estimating the leaf area, productivity and biomass stock of stands planted with the studied species that are of similar age using simple inventory data. As an extension of this study, the biomass functions reported here were used to estimate the total biomass stock of the same plots and sites presented in this study [23].

Eleven (CR site) or ten (CF site) years after treatments ended, only western redcedar showed an effect of VM treatments on branch-level foliage allometry. Individual branches of similar size (diameter) and position within the crown had more branch-level foliage biomass when growing on plots without VM after planting. The trees growing in these control plots were shorter, maybe having less shading to lower portions of the crown, which in turn, may improve foliage retention as the leaf longevity of western redcedar has been shown to increase with depth into the canopy [24]. On the other hand, for the same species, branch-level allometry of LA followed a different trend: Individual branches of similar size (diameter) and position within the crown had less branch-level LA when growing on plots without VM after planting, implying that for trees growing under sustained VM, branches of similar size and position within the crown had larger SLA (larger foliage area per unit mass), as those branches had more foliage biomass. This difference is SLA is likely due to the contrasting growing conditions of western redcedar VM and C plots. Western redcedar trees in the VM plots were much larger than in C plots (Table 1) and had closed canopy whereas trees in the C plots were mostly open grown due to the combined effect of smaller tree size and lower survival rate [23]. The SLA of western redcedar has been shown to increase with decreasing light availability [24] and the lower light levels in the VM plots (due to a closed canopy) could explain the increased SLA observed in these plots. 
At the CF site, the PDSI ranged between -8 to -15 during the first three growing seasons after planting (Figure 1), indicating a strong water deficit, especially on control plots subjected to intense competition. This intensive water stress at the CF site, exacerbated by large amounts of competing vegetation on control plots during the early years of establishment, was reflected in the survivorship of western redcedar, as the survival of the trees growing in control plots was about $50 \%$ of those growing under VM treatments. At the whole tree-level, only western redcedar showed a long-term effect of VM treatments on foliage biomass allometry. Trees of similar size (diameter and height) had more foliage biomass when growing on plots without VM after planting. This response is a result of the differences in branch-level allometry previously discussed. Nevertheless, as plots with VM treatment had more and bigger trees, the overall plot-level biomass was larger under VM treatment [23].

We observed differences across sites in stem volume allometry for Douglas-fir and western redcedar. Trees of similar diameter and height had larger stem volume when growing at the CR site than the $\mathrm{CF}$ site. Changes in stem tapering explain these results. Increased water deficit during the first five years was observed at the CF site, and trees growing at the CF site had less tapering for the basal stem section to DBH. This response seems to be associated with larger branches at the basal section of the stem. Increased water availability at the CR site may induce increased foliage retention and, thus, evaporative demand [25-27]. In order to supply that increased demand for water, the trees increased the sapwood area of the stem in order to supply water to those larger branches [28]. Kidombo et al. (2018) [29], working with Pinus taeda L. trees, concluded that stem tapering was affected by the amount of leaf area, decreasing stem diameter on sections immediately above or below whorls with reduced leaf area.

Species differences for branch biomass partitioning are indicators of growth efficiency and degree of shade tolerance. Douglas-fir and western hemlock had branches with $45 \%$ less fraction of foliage in their branches than western redcedar, but this species had the lowest number of branches, compensating, at least partially, the larger allocation of foliage biomass per branch. At a whole-tree level, total crown biomass accounted for most of the biomass of western redcedar trees. The higher allocation of resources to foliage development observed for western redcedar may be due to this species evolving to grow in low light environments as it is the most shade tolerant of the species tested [30].

Only stemwood biomass (W) of Douglas-fir, western hemlock and grand fir needed DBH and HT as predictors. The lack of significance of HT for western redcedar was associated with a high degree of collinearity between DBH and HT for the species. Working with P. taeda and Pinus elliottii Engelm. trees, Gonzalez-Benecke et al. (2014) [31] reported that there was little gain when HT was used, in addition to DBH, to estimate foliage and branch biomass. The lack of significance of HT for crown-related estimates indicate that after crown recession starts, stem diameter is a better predictor as it is directly correlated with sapwood area.

Several studies have shown a strong relationship between sapwood area and leaf area [32,33]. In this study, we presented a strong relationship between BA and LAI for the four-species studied. This indicates that the studied species may have similar sapwood to leaf area ratios, as the trees have little heartwood development at the age of sampling. Even though a similar trend has been reported in other studies [34,35], this is the first study reporting the same relationship for Douglas-fir, western hemlock, western redcedar, and grand fir trees of the same age. This relationship is helpful as BA can be easily determined and be used as a method of estimating LAI for stands of a similar age.

Biomass and leaf area equations can be used to estimate different ecosystem attributes, such as ecosystem C balance [36], net primary productivity [37], nutrient dynamics [38], light use efficiency [39] and water yield [40], among many others. The allometric equations developed in this study represent an improvement over other published equations for calculating the biomass stock of crop trees at the study sites [16-19] and largely improved the accuracy and precision of above ground biomass estimations on the study sites tested. In our case, accurate estimates of crop tree biomass for these studies sites is important as a further research is being conducted on the impact of VM treatments on 
the total ecosystem biomass stock (soil + forest floor + understory + midstory + crop tree biomass), net primary productivity and nutrient balance.

\section{Conclusions}

This study represents, to the authors' knowledge, the first attempt to quantify how vegetation management treatments impact the long-term allometry of planted conifer species in the Pacific Northwest of United States. Allometric equations were developed to predict individual tree and component biomass for fifteen- to sixteen-year-old Douglas-fir, western hemlock, western redcedar and grand fir trees. These equations are useful for estimating the biomass of stands of similar age and represent an improvement over previously published equations for the ages and species tested. Sustained vegetation management during the first five years of stand establishment did not affect the allometry of Douglas-fir, western hemlock or grand fir. For western redcedar, however, trees of similar size (diameter and height) had greater foliage biomass when growing in the control plots than the VM treated plots. This may be the result of the more open conditions in western redcedar control plots which had, on average, smaller crop trees and higher mortality rates. There was an effect of site on the stem volume allometry of Douglas-fir and western redcedar such that trees of similar size (diameter and height) had larger stem volumes when growing at the CR site than the CF site. This was due to differences in stem tapering. A strong and linear relationship was found between stand basal area and leaf area index that was shared for all studied species suggesting that all of the species in this study share a similar sapwood to leaf area ratio as there is little to no heartwood at the evaluation age.

Author Contributions: C.A.G.-B. conceived of and designed the experiments, and wrote the paper. H.N.F. and M.G.W. performed field and lab measurements, analyzed the data and wrote the paper.

Funding: This research was supported by the Forest Engineering, Resources and Management Department and the Vegetation Management Research Cooperative at Oregon State University.

Acknowledgments: This research was supported by the Starker Forests Inc., Cascade Timber Consulting Inc., the Oregon State University Forest Engineering, Resources and Management Department and the Vegetation Management Research Cooperative at Oregon State University. Special thanks go to Jon Buzawa, Thiago Moreira and Sara Lowe, for their help with data collection.

Conflicts of Interest: The authors declare no conflict of interest and the founding sponsors had no role in the design of the study; in the collection, analyses, or interpretation of data; in the writing of the manuscript, and in the decision to publish the results.

\section{Appendix A}

Table A1. Parameter estimates and fit statistic of the equation for predicting projected leaf area index $\left(\mathrm{LAI}, \mathrm{m}^{2} \mathrm{~m}^{-2}\right.$ ) for Douglas-fir, western hemlock, western redcedar, and grand fir stands growing on sites located in the central Coast Range and the Cascade foothills of western Oregon.

\begin{tabular}{cccccc}
\hline Model & Parameter & Parameter Estimate & SE & $\boldsymbol{R}^{\mathbf{2}}$ & RMSE \\
\hline \multirow{2}{*}{$\mathrm{LAI}=a+b \cdot \mathrm{BA}$} & $a$ & 0.5038 & 0.1463 & \multirow{2}{*}{0.98} & 0.428
\end{tabular}

BA: crop tree basal area $\left(\mathrm{m}^{2} \mathrm{ha}^{-1}\right)$; LAI: projected leaf area index $\left(\mathrm{m}^{2} \mathrm{~m}^{-2}\right) ; R^{2}$ : coefficient of determination; RMSE: root mean square error. For all parameter estimates: $p<0.05$.

\section{References}

1. Jenkins, J.C.; Chojnacky, D.C.; Heath, L.S.; Birdsey, R.A. National-scale biomass estimators for United States tree species. For. Sci. 2003, 49, 12-35.

2. Madgwick, H.; Satoo, T. On estimating the aboveground weights of tree stands. Ecology 1975, 56, 1446-1450. [CrossRef] 
3. Johnsen, K.H.; Keyser, T.; Butnor, J.R.; Gonzalez-Benecke, C.A.; Kaczmarek, D.J.; Maier, C.A.; McCarthy, H.R.; Sun, G. Forest productivity and carbon sequestration of forests in the southern United States. In Climate Change Adaptation and Mitigation Management Options: A Guide for Natural Resource Managers in Southern Forest Ecosystems; Vose, J.M., Klepzig, K.D., Eds.; CRC Press: Boca Raton, FL, USA, 2014; pp. 193-247.

4. Bartelink, H.H. Allometric relationships on biomass and needle area of Douglas-fir. For. Ecol. Manag. 1996, 86, 193-203. [CrossRef]

5. Causton, D.R. Biometrical, structural and physiological relationships among tree parts. In Attributes of Trees as Crop Plants; Cannel, M.G.R., Jackson, J.E., Eds.; Institute of Terrestrial Ecology: Huntingdon, UK, 1985; pp. 137-159.

6. Landsberg, J.J.; Waring, R.H. A generalised model of forest productivity using simplified concepts of radiation-use efficiency, carbon balance and partitioning. For. Ecol. Manag. 1997, 95, 209-228. [CrossRef]

7. Brix, H. Effects of thinning and nitrogen fertilization on branch and foliage production in Douglas-fir. Can. J. For. Res. 1981, 11, 502-511. [CrossRef]

8. Grier, C.C.; Lee, K.M.; Archibald, R.M. Effect of urea fertilization on allometric relations in young Douglas-fir trees. Can. J. For. Res. 1984, 14, 900-904. [CrossRef]

9. Balandier, P.; Collet, C.; Miller, J.H.; Reynolds, P.E.; Zedaker, S.M. Designing forest vegetation management strategies based on the mechanisms and dynamics of crop tree competition by neighboring vegetation. Forestry 2006, 79, 3-27. [CrossRef]

10. Wagner, R.G.; Little, K.M.; Richardson, B.; Mcnabb, K. The role of vegetation management for enhancing productivity of the world's forests. Forestry 2006, 79, 57-79. [CrossRef]

11. Dimock, E.J., II; Beebe, T.F.; Collard, E.B. Planting-site preparation with herbicides to aid conifer reforestation. Weed Sci. 1983, 31, 215-221.

12. Newton, M.; Preest, D.S. Growth and water relations of Douglas fir (Pseudotsuga menziesii) seedlings under different weed control regimes. Weed Sci. 1988, 36, 653-662.

13. Rose, R.; Rosner, L.S.; Ketchum, J.S. Twelfth-year response of Douglas-fir to area of weed control and herbaceous versus woody weed control treatments. Can. J. For. Res. 2006, 36, 2464-2473. [CrossRef]

14. Dinger, E.J.; Rose, R. Integration of soil moisture, xylem water potential, and fall-spring herbicide treatments to achieve the maximum growth response in newly planted Douglas-fir seedlings. Can. J. For. Res. 2009, 39, 1401-1414. [CrossRef]

15. Maguire, D.A.; Mainwaring, D.B.; Rose, R.; Garber, S.M.; Dinger, E.J. Response of coastal Douglas-fir and competing vegetation to repeated and delayed weed control treatments during early plantation development. Can. J. For. Res. 2009, 39, 1208-1219. [CrossRef]

16. Shaw, D.L., Jr. Biomass equations for Douglas-fir, western hemlock, and red cedar in Washington and Oregon. In Forest Resource Inventories Workshop Proceedings; Colorado State University: Fort Collins, CO, USA, 1979; pp. 763-781.

17. Gholz, H.L. Environmental limits on aboveground net primary production, leaf area, and biomass in vegetation zones of the Pacific Northwest. Ecology 1982, 63, 469-481. [CrossRef]

18. Standish, J.T.; Manning, G.H.; Demaerschalk, J.P. Development of Biomass Equations for British Columbia Tree Species; Information Report BC-X-264; Pacific Forest Research Centre: Victoria, BC, Canada, 1985; p. 48.

19. Chojnacky, D.C.; Heath, L.S.; Jenkins, J.C. Updated generalized biomass equations for North American tree species. Forestry 2014, 87, 129-151. [CrossRef]

20. Briggs, D. Management Practices on Pacific Northwest West-Side Industrial Forest Lands, 1991-2005: With Projections to 2010; Working Paper; Stand Management Cooperative (SMC): Seattle, WA, USA, 2007.

21. Haase, D.L.; Khadduri, N.; Mason, E.; Dumroese, R.K. Relationships among chilling hours, photoperiod, calendar date, cold hardiness, seed source, and storage of Douglas-fir seedlings. Tree Plants Notes 2016, 59, $52-63$.

22. Tripathi, A.M.; Fischer, M.; Orság, M.; Marek, M.V.; Žalud, Z.; Trnka, M. Evaluation of indirect measurement method of seasonal patterns of leaf area index in a high-density short rotation coppice culture of poplar. Acta Univ. Agric. Silvic. Mendel. Brun. 2016, 64, 549-556. [CrossRef]

23. Flamenco, H.N.; Gonzalez-Benecke, C.A.; Wightman, M.G. Long-term effects of vegetation management on biomass stock of four coniferous species in the Pacific Northwest United States. For. Ecol. Manag. 2018, in review. 
24. Harlow, B.A.; Duursma, R.A.; Marshall, J.D. Leaf longevity of western red cedar (Thuja plicata) increases with depth in the canopy. Tree Physiol. 2005, 25, 557-562. [CrossRef] [PubMed]

25. Wang, G.G.; Qian, H.; Klinka, K. Growth of Thuja plicata seedlings along a light gradient. Can. J. Bot. 1994, 72, 1749-1757. [CrossRef]

26. Del Rio, E.; Berg, A. Specific leaf area of Douglas-fir reproduction as affected by light and needle age. For. Sci. 1979, 25, 183-186.

27. Mencuccini, M.; Grace, J. Climate influences the leaf area/sapwood area ratio in Scots pine. Tree Physiol. 1995, 15, 1-10. [CrossRef] [PubMed]

28. Martinez-Villalta, J.; Cochard, H.; Mencuccini, M.; Sterck, F.; Herrero, A.; Korhonen, J.F.J.; Llorens, P.; Nikinmaa, E.; Nolè, A.; Poyatos, R.; et al. Hydraulic adjustment of Scots pine across Europe. New Phytol. 2009, 184, 353-364. [CrossRef] [PubMed]

29. Kidombo, S.D.; Dean, T.J. Growth of tree diameter and stem taper as affected by reduced leaf area on selected branch whorls. Can. J. For. Res. 2018, 48, 317-323. [CrossRef]

30. Carter, R.E.; Klinka, K. Variation in shade tolerance of Douglas fir, western hemlock, and western red cedar in coastal British Columbia. For. Ecol. Manag. 1992, 55, 87-105. [CrossRef]

31. Gonzalez-Benecke, C.A.; Gezan, S.A.; Albaugh, T.J.; Allen, H.L.; Burkhart, H.E.; Fox, T.R.; Jokela, E.J.; Maier, C.A.; Martin, T.A.; Rubilar, R.A.; et al. Local and general above-stump biomass functions for loblolly and slash pine trees. For. Ecol. Manag. 2014, 334, 254-276. [CrossRef]

32. Bancalari, M.A.E.; Perry, D.A. Distribution and increment of biomass in adjacent young Douglas-fir stands with different early growth rates. Can. J. For. Res. 1986, 17, 722-730. [CrossRef]

33. Waring, R.H.; Schroeder, P.E.; Oren, R. Application of the pipe model theory to predict canopy leaf area. Can. J. For. Res. 1982, 12, 556-560. [CrossRef]

34. Eckrich, C.A.; Flaherty, E.A.; Ben-David, M. Estimating leaf area index in Southeast Alaska: A comparison of two techniques. PLoS ONE, 2013, 8, e77642. [CrossRef] [PubMed]

35. O'Grady, A.P.; Chen, X.; Eamus, D.; Hutley, L.B. Composition, leaf area index and standing biomass of eucalypt open forests near Darwin in the Northern Territory, Australia. Aust. J. Bot. 2000, 48, 629-638. [CrossRef]

36. Harmon, M.E.; Marks, B. Effects of silvicultural practices on carbon stores in Douglas-fir-western hemlock forests in the Pacific Northwest, U.S.A.: Results from a simulation model. Can. J. For. Res. 2002, 32, 863-877. [CrossRef]

37. Harmon, M.E.; Bible, K.; Ryan, M.G.; Shaw, D.C.; Chen, H.; Klopatek, J.; Li, X. Production, respiration, and overall carbon balance in an old-growth Pseudotsuga-Tsuga forest ecosystem. Ecosystems 2004, 7, 498-512. [CrossRef]

38. Ponette, Q.; Ranger, J.; Ottorini, J.-M.; Ulrich, E. Aboveground biomass and nutrient content of five Douglas-fir stands in France. For. Ecol. Manag. 2001, 142, 109-127. [CrossRef]

39. Waring, R.H.; Coops, N.C.; Running, S.W. Predicting satellite-derived patterns of large-scale disturbances in forests of the Pacific Northwest Region in response to recent climatic variation. Rem. Sens. Environ. 2011, 115, 3554-3566. [CrossRef]

40. McLaughlin, D.L.; Kaplan, D.A.; Cohen, M.J. Managing forests for increased regional water yield in the Southeastern U.S. coastal plain. J. Am. Water Resour. Assoc. 2013, 49, 953-965. [CrossRef]

(C) 2018 by the authors. Licensee MDPI, Basel, Switzerland. This article is an open access article distributed under the terms and conditions of the Creative Commons Attribution (CC BY) license (http:/ / creativecommons.org/licenses/by/4.0/). 